
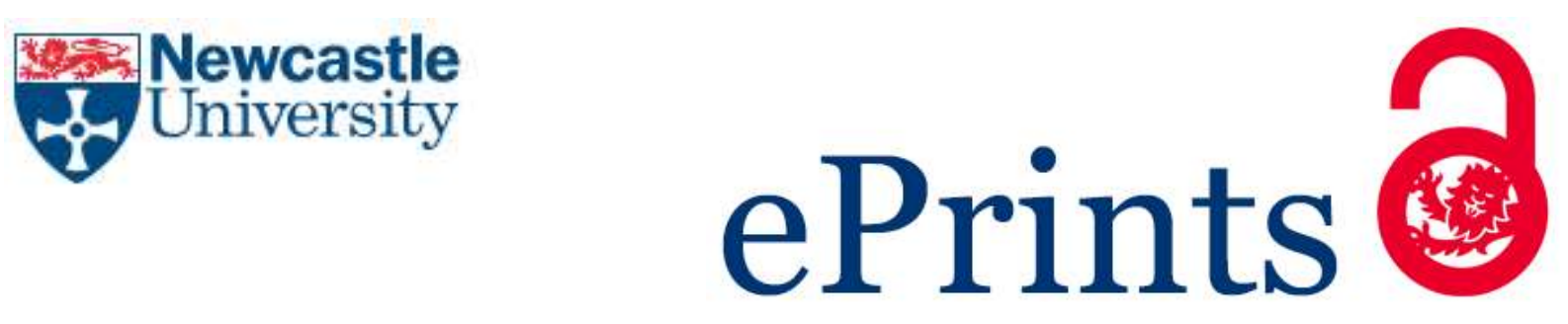

Clarke D, Lochhead J, Metzer D, Griffiths D, Nooshin L, Rollefson G, Yang HL, Mugovhani NG, Piekut B, Lewis GE, Toop D, Manabe N, Redgate R, Thompson M.

Defining twentieth-and twenty-first century music.

Twentieth-Century Music 2018, 14(3), 411-462.

\title{
Copyright:
}

This article has been published in a revised form in Twentieth-Century Music

https://doi.org/10.1017/S1478572217000342. This version is free to view and download for private research and study only. Not for re-distribution, re-sale or use in derivative works. (C) Cambridge University Press, 2018.

DOI link to article:

https://doi.org/10.1017/S1478572217000342

Date deposited:

$16 / 01 / 2018$ 


\title{
$<\mathrm{AT}>$ Forum
}

\section{Defining Twentieth- and Twenty-First-Century Music}

\author{
$<$ AU $>$ David Clarke, Convener and Editor
}

\section{<A>Introduction: Thinking Together}

$<$ AU >David Clarke

$<$ Txt $>$ What do we mean by 'twentieth-century music'? And how are we to square this with the musics of a twenty-first century that is now nearing the end of its second decade? These and other questions are salient for a journal that identifies the former century in its title yet regards the latter as equally within its remit. Just how are we to think the two centuries together? Should we consider the music of the twenty-first century as a continuation of tendencies from the late twentieth? Or are there tendencies within musical production and consumption that have a definitively twenty-first-century character and so mark out the beginning of a new era? If so, when and with what, iconically speaking, did the twenty-first century begin and the twentieth end? Or do these historiographic categories even continue to have currency?

Such questions are pressing on both pragmatic and epistemological grounds. For the journal and its editorial board there's the matter of whether a change of name might be timely, and, if so, to what. More fundamentally, there is the wider theoretical issue of how we, as witnesses to a new century and millennium, are to relate developments in music to the processes of, and the writing of, history - and indeed which, and whose, history?

Consistent with its pluralistic stance towards the period (its mission to promote knowledge of musics in all relevant genres by means of all relevant epistemologies), the journal has here convened a dozen or so contributors to offer 
their own takes on these questions. ${ }^{1}$ Their task was to offer a concise, speculative, even provocative statement on how they see these things from their particular specialism as music writers and/or practitioners. While it would have been invidious to ask them also to act as representatives of the particular field they occupy, we have nonetheless been mindful to invite a range of authors who speak from different perspectives of genre, gender, generation, and geography.

\section{$<$ Break $>* * *$}

$<$ Txt $>$ The question of who is writing is no less significant than ones about definition. What 'we' mean by twentieth-century music is inseparable from who 'we' is, in which cultural situation, and at which place and time. As more than one of the following authors reminds us, for much of its history, 'twentieth-century music' has tended to mean modernist or avant-garde art music composed in the West by men, and has been documented as such by scholars of a similar complexion. Paradigm shifts within musicology in the later twentieth century, of which TCM's pluralism is symptomatic, have begun to offer a corrective to such a hegemony. Yet even here it seems there is more to be done - Hon-Lun Yang's article opens with some salutary statistics about the journal's demographics of topics and authors that among other things reveal a continuing Western bias.

Nonetheless, in commissioning the present forum we wanted to reaffirm our recognition that music of the twentieth and twenty-first centuries will look different

\footnotetext{
${ }^{1}$ A similar colloquy was convened in 2011 by the Journal of the American Musicological Society, though from an exclusively Americanist perspective. See Charles Horishi Garrett and Carol J. Oja, 'Studying U.S. Music in the Twenty-First Century', Journal of the American Musicological Society 64/3 (2011).
} 
from elsewhere in the world - hence contributions by Ndwamato George Mugovhani on South Africa, Yang on China, and the multi-voiced mini-colloquy of ethnomusicologists mobilized by Laudan Nooshin and Griff Rolleson. We could (and perhaps ideally should) have gone for still greater geographical diversification, but, even so, it will take more than a multiplication of local perspectives to correct inherited hegemonic and hypostatizing constructions of music in the period; it is also a question of critically analysing how different cultures relate and connect, under conditions not always benign or equitable. Hence, contributions by George Lewis and Noriko Manabe also play a role in examining the legacies of, respectively, colonization and globalization in the twenty-first century. Further, Nooshin, Rollefson, and their ethnomusicological associates caution against 'the normative assumption that one particular historical periodization is universal', adding that '1997' was the year 1376 according to the Iranian solar calendar. With this, any unified notion of 'the twentieth century' would seem to crumble.

There are resonances here with the writings of postcolonial theorist Homi K. Bhabha, who argues against the universalization and depoliticization of time: 'Cultural difference must not be understood as the free play of polarities and pluralities in the homogeneous empty time of the national community. ${ }^{2}$ In this he also invokes Benedict Anderson's critique of the "narrative of the "meanwhile": $<$ Ext $>$ The steady onward clocking of calendrical time ... gives the imagined world ... a [specious] sociological solidity; it links together diverse acts and

\footnotetext{
${ }^{2}$ Homi K. Bhahba, The Location of Culture (London and New York: Routledge 2004), 232.
} 
actors ... who are entirely unaware of each other, except as a function of this synchronicity of time. ${ }^{3}$

In other words, different cultures experience incompatible, non-synchronous narratives of history and identity; and colonialism is one place where those incompatibilities are played out - it just depends on who is narrating. As Janaki Bakhle recounts in her book Two Men and Music, for India in the first half of the twentieth century the experience of modernity was inseparable from the struggle for independence from British imperialist rule. ${ }^{4}$ In this respect, high-cultural practices such as Indian classical music in its various avatars became one of the weapons through which to articulate a counter-hegemonic national identity, no matter that this was founded on pre-modern (or, on Regula Qureshi's view, feudal) social and pedagogic relations. ${ }^{5}$ Contemporaneously with the compositions of Schoenberg and

\footnotetext{
${ }^{3}$ Bhahba, The Location of Culture, 226, referencing Benedict Anderson, Imagined Communities: Reflections on the Origins of the Spread of Nationalism (London: Verso, 1983), 30. While Bhabha's concern is with diverse communities within a nation, in an ever more globalized world it is arguably not a violation to project his critique back onto an international stage, as I do here.

${ }^{4}$ Janaki Bakhle, Two Men and Music: Nationalism and the Making of an Indian Classical Tradition (Oxford: Oxford University Press, 2005).

${ }^{5}$ See Regula B. Qureshi, 'Mode of Production and Musical Production: Is Hindustani Music Feudal?', in Music and Marx: Ideas, Practice, Politics, ed. Regula B. Qureshi. (New York: Routledge, 2002).
} 
Bartók, then, music in India's twentieth century played out under different conditions of resistance and a different relationship with its own past. $^{6}$

$$
<\text { Break }>* * *
$$

$<$ Txt $>$ By now it will be evident that, in tandem with previewing key issues raised in this forum, I am also formulating my own thoughts on the matter. Or re-synthesizing them. In an earlier article I had adapted these notions from Bhabha to navigate a different but related fault line: the twentieth century's 'great divide', as Andreas Huyssen couches it, between mass culture and modernism (or between popular and art music, to adapt the notion to our particular context). As I put it then, how are we to think the classical and vernacular - seemingly incommensurable socio-aesthetic spheres - together? ${ }^{7}$

Certainly, in most scholarly histories of twentieth-century music we have not. Popular music has tended either to occupy a supplemental or marginal position, or been left to narrate its own stories. In his article, Dai Griffiths does hold both fields in mutual awareness even as he alludes to the various intertwining threads and periodizations of popular music(s) in the twentieth century. His voice is trenchant here because it speaks for how popular music studies (drawing strength from pop's own international habitus and reach) has played its part in dislodging high modernism from centre stage in our accounts of the period. Yet one subterranean affinity those

\footnotetext{
${ }^{6}$ I discuss this matter at greater length in David Clarke, 'Different Resistances: A Comparative View of Indian and Western Classical Music in the Modern Era', Contemporary Music Review 32/2-3 (2013).

${ }^{7}$ David Clarke, 'Elvis and Darmstadt: The IMS Cut', Hamburger Jahrbuch für Musikwissenschaft (special issue: Zwischen 'U' und 'E') 27 (2011), 11.
} 
'high' cultural practices might display with their 'low' musical other is their potential for participation in 'political struggle and human agency' - to borrow a phrase from Richard Middleton which Griffiths savours. The critical and resistive legacies of the avant-garde, as propounded below by Roger Redgate, are too important to relativize into oblivion; this would make us complicit with the alleged death of the subject, death of art, end of history. For Griffiths/Middleton, what is political in the popular is, among other things, the possibility of 'interconnections and dependencies' between 'real people in a real world'. On the other hand, Redgate invokes Peter Bürger's warning about the culture industry's 'false elimination of the distance between art and life'. Pertinent here is a leitmotif from Alain Badiou's The Century: that the twentieth-century avant-garde, in its 'critique of semblance ... representation, mimesis and the "natural", tapped into the Real in a different, Lacanian sense. ${ }^{8}$ These different perspectives on what is real may be incommensurable, yet they may not fail to intersect either. ${ }^{9}$

$$
<\text { Break }>* * *
$$

${ }^{8}$ Alain Badiou, The Century, trans. Alberto Toscano (Cambridge and Malden, MA: Polity, 2007), 131.

${ }^{9}$ Their critical counterparts include the 'grand' and 'little' traditions of sociology that Tia DeNora counterpoints in the first chapter of her Music in Everyday Life

(Cambridge: Cambridge University Press, 2000). I also tease out some of the tensions between these critical positions throughout my article 'Beyond the Global Imaginary: Decoding BBC Radio 3's Late Junction', Radical Musicology 2 (2007), www.radicalmusicology.org.uk/2007/Clarke.htm (accessed 20 September 2017). 
$<$ Txt $>$ Writing on the periodization of nineteenth-century music, Carl Dahlhaus argues that 'any historian interested in establishing connections will naturally gravitate towards the emergence and crystallization of the new rather than the demise and disintegration of the old' ${ }^{10}$ If anything could be said to characterize our current cultural conjuncture, it might be the questioning, traversing, permeability, erosion, and even melting down of generic and geographic boundaries. Yet do these symptoms mark the crystallization of a new century, or the demise and disintegration of the old one? And even if we could identify, in Badiou's memorable phrase, the 'instant of exception that effaces the twentieth century, ${ }^{11}$ - of which there have been more than enough candidates before and since the millennium - on what grounds are we to relate such social, economic, and geopolitical events to historical developments in music and culture? As Dahlhaus points out, "relative autonomy" - which even Marxists concede a place in the "superstructure" - enables us to emphasize connections within music history itself' ${ }^{12}$ Fredric Jameson in his article 'Periodizing the 60s' indeed acknowledges the relative autonomy of different spheres or 'levels' of connectivity (the philosophical, political, cultural, and economic) even as he maintains a more specifically Marxist insistence on the contradictions of

\footnotetext{
${ }^{10}$ Carl Dahlhaus, Nineteenth-Century Music, trans. J. Bradford Robinson (Berkeley, CA, and London: University of California Press, 1989), 2.

${ }^{11}$ Badiou, The Century, 1.

${ }^{12}$ Dahlhaus, Nineteenth-Century Music, 1.
} 
socioeconomic relationships as in some sense primary. ${ }^{13}$ My own hunch, worked through in what follows, is that, for present purposes, we need paradoxically to emphasize the significance of music's relative autonomy more than Jameson might, and look for a more formal connection between spheres than is granted by Dahlhaus.

That the ensuing collection of articles suggests a range of answers to the question of periodization is perhaps less surprising than the fact that strands of cohesion can be discerned across its polyphony of viewpoints. Various contributors sound their scepticism about a centennial taxonomy. Others - in a possibly not incompatible standpoint - are comfortable with the idea of a long twentieth century extending up to the present, but insist on either a corresponding sense of global connectivity (Yang) or a counterpointing historical principle of shorter conjunctures defined thematically by social or aesthetic movements (David Metzer, Judy Lochhead). Most significant of all is a sense of a new period emerging at some point after the Second World War - variable according to how you pinpoint the 'crystallization of the new'. Following Benjamin Piekut's lead, we might construe the decades since 1945 up to the present as a new and continuous phase in which the sonic becomes a new, deconstructive category of musical creation and critical analysis. ${ }^{14}$ Or we might locate a distinctive shift around the inception of the twenty-

${ }^{13}$ Jameson maps homologies between the various 'levels' of historical change specifically in the breaks that these several relatively autonomous spheres make with the past. See Fredric Jameson, 'Periodizing the 60s', Social Text 9/10 (1984), 179.

\footnotetext{
${ }^{14} \mathrm{~A}$ fact reflected in both the substance and the style of several recent texts, which tend analogously to blur boundaries between academic and populist idioms - for example, Christoph Cox and Daniel Warner, eds., Audio Culture: Readings in Modern Music (New York and London: Continuum, 2007);
} 
first century. Lewis argues for the latter periodization, on the evidence of a 'new sonic créolité ... fuelled by a trope of improvisation-as-mobility'. David Toop likewise discerns a new phase in the practices of free improvisation at this moment, enabled most conspicuously by the rise of digital technologies. For Manabe, internet streaming becomes a hallmark of twenty-first-century musical consumption. Lochhead also sees the rise of the digital as a watershed, but situates this around the mid-1980s.

Like Lochhead and others, I would identify roughly the last quarter of the twentieth century as a likely point of crystallization. More than a passing co-existence of tendencies on their way out and tendencies on their way in, this conjuncture is marked by simultaneous and contradictory conservatism and progressiveness. The later 1970s and 1980s marked the moment when Peter Maxwell Davies stopped writing works with titles such as Eight Songs for a Mad King and started writing symphonies and concertos; when the soundworlds of Krzystof Penderecki no longer assumed radical textural form that captures what is outside conventional tonal and rhythmic syntax (sounding the 'Real' in Badiou's sense), and reverted to an unexciting form of neo-late romanticism; when the protracted chord changes of the time-resisting processes of what used to be called 'systems music' sped up and became identified under the brand names of minimalism and postminimalism. Yet, if all this in some way marked the beginning of the musical end of the twentieth-century

Mark Prendergast, The Ambient Century: From Mahler to Trance: The Evolution of Sound in the Electronic Age (London: Bloomsbury, 2000); Alex Ross, The Rest is Noise: Listening to the Twentieth Century (London: Harper Perennial, 2009); and David Toop, Ocean of Sound: Aether Talk, Ambient Sound and Imaginary Worlds (London: Serpent's Tail, 1995). 
avant-garde, the long list of practices under Piekut's portmanteau of the 'vernacular avant garde', and others that Toop aligns with free-improv, might be seen as its new home and portending the beginning of the twenty-first.

Many of the tendencies in question are of course those of postmodernism, which Jameson famously casts as the cultural logic of late capitalism. Yet if debates around the P-word have themselves now begun to look historical, those around the relationship between music and the ascendancy of neoliberalism - late capitalism's most recent and virulent avatar - have barely begun. Marie Thompson's article here is especially timely, in particular her cautionary reminder of neoliberalism's ability to inoculate itself against all tropes of resistance. The sounding of the Real within what remains of the avant-garde - whether in art-music or vernacular form - may represent marketable forms of excess; and fluidity between genres, between composition and improvisation, between consumer and producer, may all melt into what Zygmunt Bauman has elsewhere termed 'liquid modernity' - post-genre, post-identity, posteverything.

\section{$<$ Break $>* * *$}

$<\mathrm{Txt}>$ One tempting way to interpret this conjuncture is as a long and deep interregnum - a notion which I adapt from Wolfgang Streeck's recent article on neoliberalism and globalization, and which he in turn borrows from Gramsci. ${ }^{15}$ Politically, we might place this as beginning around the moment in the 1970s when Margaret Thatcher portentously pulled out a copy of Hayek's The Constitution of

\footnotetext{
${ }^{15}$ Wolfgang Streeck, 'The Return of the Repressed', trans. Rodney Livingstone, New Left Review 104 (2017), 14ff.
} 
Liberty declaring 'this is what we believe', ${ }^{16}$ and continuing up to our current moment of Trump, Brexit, and whatever other crises in the history of an ever more deeply global geopolitics will have followed by the time you read these words (here I again betray my own cultural locus). Musically this is a period that runs just as long and deep, and perhaps might ultimately be seen as transitional on a grand scale - a process where the beginnings and ends look different, but where the outcome is still not evident - and in that sense an interregnum in Streeck's and in Grasmci's sense. These poles are coterminous at one end with the time in the West when still recognizably modernist musical art began unapologetically to re-admit pulse and tonal centricity, and did care, pace Milton Babbit, if you listened; and at the other with a world where the very concept of a work, or the category of a composer who writes them, is no longer taken for granted (or recognized as only ever having had local currency); where the emancipation of the dissonance has been supplanted by the emancipation of the track; where - in a poignantly democratizing move - both the work concept and the album concept have been upstaged by the playlist. ${ }^{17}$

What this last suggests is that while musical sound worlds of the twenty-first century continue to have strong affinities with those of the twentieth, what has changed is the complexion of our processes of production, consumption, and, importantly, discourse amidst a new, global order of digital connectivity. Perhaps this

\footnotetext{
${ }^{16}$ Margaret Thatcher Foundation, 'Thatcher, Hayek \& Friedman', www.margaretthatcher.org/archive/Hayek.asp.

${ }^{17}$ In graciously declining to write for this forum, Brian Ferneyhough wrote: 'Things are breaking up; where individual slivers will lodge is anyone's guess. Probably someone younger than me would be in a better position to catch the birds in flight' (pers. comm., August 2016).
} 
is what may have enabled the twenty-first century to have slipped in without our knowing it, ahead of the dateline, even as it has yet to fully cast itself off from the twentieth. $^{18}$

If neoliberalism forms the socioeconomic background or base for these conditions (to grant a nod towards Marxist dialectical materialism), the question of how we in our radical cultural and epistemological diversity are to emancipate ourselves from it into a genuinely new age has no obvious answer. A gloomy view would resign itself to the assimilation of everything to the principle of the commodity and the fluidity of the marketplace - something with which postmodernism, whatever else it has brought, has been profoundly complicit. Less pessimistically, the will to make music, to create something we might still want to call art (in an ever more inclusive sense), may continue to afford subjective non-identity against those principles - which makes it all the more urgent that in our discourses about them we grant those musical practices, whatever their sphere, their moment of relative autonomy. In turn, those discourses may be no less significant than creative activity itself, and may even be counted as such. To borrow Thompson's closing point in making my own, a vital part of our search might be for a 'post-musicological' culture that refuses disciplinary isolationism. We still have some way to go, but the signs since the end of the last century are surely that we are off the starting blocks.

\section{$<A>$ What's in a Name? Music of the Present}

\footnotetext{
${ }^{18}$ As if in recognition of this transitional situation, a number of commentators within and outwith this forum, myself included, have independently come up with Music 20/21 as a possible new title for the journal.
} 


\section{$<$ AU >Judy Lochhead}

$<$ Txt $>$ We have reached a tipping point: the designation 'music of the twentieth and twenty-first centuries' no longer makes any sense. A recent teaching experience serves as entry into the questions posed to this forum.

Since the late 1980s I have taught a biennial class on contemporary classical music for graduate students. I titled it 'Music Since 1950' using a simple point midcentury that aligns well with post-Second World War demarcations used in other fields. Since I first offered the class, its temporal spread has expanded from about thirty-five to sixty-five years. In autumn 2016 I took a somewhat different approach to the modified chronological approach of previous years. The first half of the class was devoted to the post-war canonical works and ideas that all well-educated graduate students should know: the major works by Boulez, Babbitt, Stockhausen, Cage, Berio, Carter, Rzewski, Oliveros, Reich, and others until about 1985. I did call attention to the compositional threads connecting these composers - serialism, new technologies, indeterminacy/chance, politics, minimalism - but presented them mostly chronologically, linking compositional thought to other social, economic, political, intellectual, and technological trends. By taking a chronological and canonic approach in the first part of the class, I could develop historical notions of influence on and from those canonic composers. Such historical narratives have a powerful explanatory function, but at the same time they assign undue weight to a few historical actors while often excluding compositional voices that diverge from them.

For the second half of the class, I employed a thematic approach, linking works and composers through relatively broad trends (the themes and the associated composers are shown in Table 1). This allowed me to draw connections or divergences between works over a relatively long temporal span that extends to the 
present day and to make more robust connections with social, economic, political, intellectual, and technological trends. I have found this approach productive, notwithstanding a few downsides - for instance, identifying a composer in one theme can suggest that all her/his works fall into that category; the taxonomy risks being over-simplistic, inhibiting connections across thematic boundaries; and the process of determining themes may exclude composers whose music lies outside predominant trends.

$<$ Capt $>$ Table 1 Themes and associated composers.

\begin{tabular}{|l|l|}
\hline Theme & Composers \\
\hline $\begin{array}{l}\text { Postmodernism in the } \\
\text { Americas }\end{array}$ & $\begin{array}{l}\text { George Rochberg, George Crumb, William } \\
\text { Bolcom }\end{array}$ \\
\hline Postmodernism in Europe & $\begin{array}{l}\text { Sofia Gubaidulina, Arvo Part, Gerard } \\
\text { Grisey, Alfred Schnittke }\end{array}$ \\
\hline Complexities/Simplicities & $\begin{array}{l}\text { Brian Ferneyhough, Jason Eckardt, George } \\
\text { Lewis, Andrew Norman, George Benjamin, } \\
\text { Hans Abrahamsen, David Lang }\end{array}$ \\
\hline Sonic Materialisms: & $\begin{array}{l}\text { Helmut Lachenmann, Chaya Czernowin, } \\
\text { Olga Neuwirth, Salvatore Sciarrino, Mark } \\
\text { Applebaum, Ashley Fure }\end{array}$ \\
\hline Syncretisms & $\begin{array}{l}\text { Chen Yi, John Adams, Dan Visconti, Sara } \\
\text { Kirkland Snider, Bryce Dessner }\end{array}$ \\
\hline Places: Eco and Neo & $\begin{array}{l}\text { Annea Lockwood, John Luther Adams, Anna } \\
\text { Thorvaldsdottir, Thomas Adès, Julia Wolfe }\end{array}$ \\
\hline
\end{tabular}

$<$ Txt $>$ The two models I describe here have some resonances with the diachronic and synchronic modes of explanation proposed by Ferdinand de Saussure in his Cours de linguistique générale in the early years of the twentieth century. ${ }^{19}$ Saussure

${ }^{19}$ See Ferdinand de Saussure, Cours de linguistique générale, ed. Charles Bally and Albert Sechehaye with Albert Riedlinger (Paris: Payot, 1960). 
advocated a synchronic study of language, approaching it through its internal structural relations. He opposed this structural approach to a diachronic approach, which involves an inevitable search for origins and futures - an approach deflecting attention away from the present. The distinction between synchronic and diachronic approaches received considerable attention in debates surrounding structuralism and post-structuralism in the 1960s and 1970s; it also surfaced in discussions about the historiography of music during that time, notably in accounts by Carl Dahlhaus, Joseph Kerman, and Leo Treitler. ${ }^{20}$ At around the same time, some scholars turned towards questions of 'the present'. In Music, the Arts, and Ideas (1967), Leonard Meyer observed that no single musical style dominated, that the present was characterized by a 'multiplicity of quite different styles in a fluctuating and dynamic steady-state'. ${ }^{21}$ This convergence of debates about music historiography and Meyer's observation regarding stylistic stasis is certainly more than coincidence. Under Meyer's particular historiographical construction, once the two dominant trends of integral serialism and indeterminacy gave way to textural music, minimalism, neoromanticism, polystylism, etc., no single historical trajectory could be traced. ${ }^{22}$ For

\footnotetext{
${ }^{20}$ See Carl Dahlhaus, Grundlagen der Musikgeschichte (Cologne: Musikverlag Gerig, 1977); Joseph Kerman, 'A Profile for American Musicology', Journal of the American Musicological Society xviii (1965); and Leo Treitler, Music and the Historical Imagination (Cambridge, MA: Harvard University Press, 1989).

${ }^{21}$ See Leonard Meyer, Music, the Arts, and Ideas: Patterns and Predictions in Twentieth Century Culture (Chicago: University of Chicago Press, 1967).

${ }^{22}$ A quick glance at the headings of Paul Griffith's Modern Music and After (New York: Oxford University Press, 2010) is ample demonstration. They include: holy minimalisms, new romanticisms, new simplicities, spectralisms, new complexities, old complexities, and towards mode/meme.
} 
Meyer and other observers, the multiplicity of musical styles, including styles of past classical music and the burgeoning styles of jazz and popular music, required a rethinking of the musicological enterprise, an interdisciplinary rethinking through cultural studies, phenomenology, postmodernism, hermeneutics, cognitive linguistics, and others.

Simultaneously with 'Music since 1950', I was also teaching a 'Rock and Popular Music' class for undergraduates - same time-period but different repertoire. Never having taught these two classes simultaneously, I was struck by how closely changes in one musical tradition mirrored those in the other. ${ }^{23}$ For instance, the complexity of musical design in the Beatles' Sgt. Pepper's Lonely Hearts Club Band (1967) and the Beach Boys' Pet Sounds (1966) gave way to the simplicity of Punk; and in the classical domain the sonic complexity of integral serialism and indeterminacy gave way to the simplicity of Minimalism and Neo-Romanticism. The parallels are not exact, but they suggest that there were historical forces affecting changes in each of these traditions. While not causally determinative, these forces emanate from such factors as the development of music technologies for performance, composition, and listening; the modes by which people buy music; the way people use music in their daily lives; and the economic, social, and political circumstances that contextualize music practices. I was also struck by a swelling multiplicity of styles and substyles in each tradition. For instance, note the different types of minimalism that one might encounter in recent discussions of twentieth-/twenty-first-

\footnotetext{
${ }^{23}$ David Clarke makes a similar observation in his 'Elvis and Darmstadt, or: Twentieth-Century Music and the Politics of Cultural Pluralism', Twentieth-Century Music 4/1 (2007), 3-44.
} 
century music - New York, European, Holy, Post, Guerilla. ${ }^{24}$ And compare that to the twenty-six different types (and more subtypes) of Metal music that are listed at Wikipedia - Folk, Doom, Death, Symphonic, Neo-Classical, Kawaii, and so on. ${ }^{25}$ In both the popular and classical traditions, there is a tendency towards a proliferation of styles and a micro-specificity of substyles. These far outpace the explanatory utility of Meyer's 'multiplicity of styles in a steady state' but they do provide some clues to an understanding of the historical forces affecting musical practices.

Three recent works afford some insight: Anna Clyne's Steelworks (2006), Caroline Shaw's 'Passacaglia' from Partita (2009-11), and Ashley Fure's Something to Hunt (2014). ${ }^{26}$ In brief, each of these works presents relatively short sonic units that transform and combine during the piece or movement, allowing for plastic and emergent structurings dependent on performance and listener. Clyne's Steelworks for flute, bass clarinet, percussion, and tape - samples voices of employees from a closing steel mill in Brooklyn, New York, combining those sounds with those of the live ensemble in ways that sonically engage the social aspects of human-machine interactions. Shaw's 'Passacaglia' - for eight a capella voices - involves timbral inflections of a chord progression through a complex vocal choreography redolent of

\footnotetext{
${ }^{24}$ List compiled from Griffiths, Modern Music and After; Joseph Auner, Music in the Twentieth and Twenty-First Centuries (New York: Norton, 2013); and Alex Ross, 'Julius Eastman’s Guerrilla Minimalism', New Yorker, 23 January 2017.

${ }^{25}$ Anon., 'Heavy Metal Genres', Wikipedia. https://en.wikipedia.org/wiki/Heavy_metal_genres (accessed 18 January 2017).

${ }^{26}$ Anna Clyne, Steelworks (New York: Boosey \& Hawkes); Ashley Fure, Something to Hunt, www.ashleyfure.com/something-to-hunt/; Caroline Shaw, 'Passacaglia', Partita (score not available).
} 
a stroll through busy urban spaces. And Fure's Something to Hunt - for oboe, sax, clarinet, violin, viola, cello, and bass - musically addresses our 'saturation with choice' with no sense that any choice promises 'progress' ${ }^{27}$ These three works speak to the present: not to a vision of unity but to a vision of the differing and the constant choices that the present entails; not to a vision of modern progress but to a vision of transformative interactions between people in actual and virtual worlds.

Which brings me back to one of this forum's key questions: do the historiographic categories of the twentieth and twenty-first centuries have any remaining explanatory power? As chronological markers they are indispensable to diachronic accounts of music history that seek to demonstrate change by tracing differences amongst works over time. For a synchronic approach seeking to identify similarities and differences amongst works, temporal boundaries of some sort provide a necessary frame to assure meaningful observations and to avoid hollow generalizations. In other words, the synchronic and the diachronic perspectives cannot be fully teased apart, as my account of autumn 2016's teaching demonstrates. The growing temporal span of 'Music since 1950' practically required some sort of refocusing, with the late 1980s - say 1985 - emerging as a demarcation point. From a diachronic perspective, the seeds of this change-point may be traced to what Hal Foster has called the 'reactionary' trends of the late 1960s and $1970 \mathrm{~s} .{ }^{28}$ From a

\footnotetext{
${ }^{27}$ Ashley Fure, Programme note for Something to Hunt, 2014. www.ashleyfure.com/something-tohunt/.

${ }^{28}$ Hal Foster, 'Postmodernism: A Preface', in The Anti-Aesthetic: Essays on Postmodern Culture, ed. Hal Foster (Port Townsend, WA: Bay Press, 1983), ix-xvi.
} 
synchronic perspective, a change-point of 1985 may be linked to the development of digital music technologies and their use in composition, performance, and listening, not just in the classical tradition but in popular and jazz ones as well. And into the present, the widespread use of digital music technologies has encouraged the increasing micro-specificity of styles because of how we listen, create, and share music.

My identification of 1985 as a significant music historical change-point whose traces we can hear in music practices of 2017 does not solve this journal's naming problem, however. 'Modern' and its 'posts' and 'afters' have no convincing explanatory power for music since 1985 . The micro-specificity of styles and the underlying embrace of difference that generates them as a significant feature of music over the last thirty years require a different approach to naming. And so I suggest a focus on the present: Music of the Present. I borrow this idea from a relatively new journal in the field of history, History of the Present. In their inaugural issue (2011), the editors write that the journal provides 'a space in which scholars can reflect on the role history plays in establishing categories of contemporary debate by making them appear inevitable, natural, or culturally necessary'. ${ }^{29}$ The journal's focus, then, is on understanding the present not simply as a necessary outcome of historical forces but also as a consequence of present and past historical discourses. Using the present as the temporal focus allows for a variety of different historical and critical approaches while also allowing for a malleable temporal span. Further, it draws attention to the

\footnotetext{
${ }^{29}$ Anon., 'Introducing the History of the Present', History of the Present 1/1 (2011), 1-4. doi:10.5406/historypresent.1.1.0001 (accessed 28 January 2017).
} 
fact that attitudes about music of the present are often affected by our notions about music of the past, a point that Treitler made some forty-five years ago in his 1969 article 'The Present as History' ${ }^{30}$ As I write in early 2017, the world seems to be at a tipping point of change, making clear that some new era is becoming manifest. This moment makes clear the imperative of tending to the present by understanding its pasts and hopefully its futures.

\section{$<$ START $>$}

\section{$<$ A $>$ Thinking Across and Within Centuries}

\section{$<$ AU $>$ David Metzer}

$<$ Txt $>$ When I was asked to contribute to this forum, I chuckled and said to myself, I never put that much weight on centuries. But then I thought of the titles of my two books: Quotation and Cultural Meaning in Twentieth-Century Music (2003) and Musical Modernism at the Turn of the Twenty-First Century (2009). So maybe I do heed centuries after all. In the latter book, I may evoke the line between the twentieth and twenty-first centuries, but I argue that explorations begun by modernist composers in the early twentieth century have continued into a new century, pouring right over that border. Yet my titular reference to 2000 shows how much that century line looms and demands that we reckon with what to make of it.

For the sake of this focused discussion, I will boil down my reckoning to this: we have made too much of centuries as categories, especially when it comes to the twenty-first century; yet given the prominence of centuries in historical accounts, we

\footnotetext{
${ }^{30}$ Treitler, 'The Present as History', in Music and the Historical Imagination.
} 
cannot dismiss them either. We instead need to come up with new historiographical perspectives as how to work both across and within them.

To get us thinking about the different sides of the colloquy topic, the editors asked whether or not the 'historiographical categories' of centuries 'continue to have currency'. I took the question literally and thought of the giant stone currency used on the South Pacific island of Yap. The stones were so big that they were never physically exchanged. They stayed put. All that changed was the knowledge of who owned them. As absurd as this system may seem, it does capture a central idea of modern currency: that the value of currency is abstract, what it represents rather than a physical value, as with a gold coin.

Centuries function like those big stones in our scholarly exchanges, except that the Yap stones may have more value than centuries do, at least as we have used them. Centuries serve as convenient categories to facilitate the disciplinary need for periodization, which especially comes through in course listings and job postings. In scholarly discussions, they stand as chronological signposts. With exceptions like this forum, we rarely question how we use centuries and the kinds of value we have assigned to them.

Just how unwieldy and unquestioned those categories have become emerges in exchanges with scholars in other disciplines. When asked by colleagues in art history or literary studies what I 'do', I respond 'twentieth- and twenty-first-century music'. They give me a puzzled look. The categories seem so vast as to be impractical. How could I deal with all that music, while they work in defined areas, like a particular movement, Abstract Expressionism, or a particular time and place, such as fin-desiècle Vienna? The twentieth and twenty-first centuries are vast, but that does not 
make them impractical for historical research. If music scholars are stuck with these categories - and it appears we are - we need to learn how to use them, to tame the expanse, to make it work for us.

My book Musical Modernism at the Turn of the Twenty-First Century embraces the expanse. It offers a new understanding of modernist music, building upon the idea that the modernist innovations of the late nineteenth and early twentieth centuries opened up enquiries into musical and aesthetic ideas that continue to unfold until the present day. Such ideas include notions of sound as a state of continuous transformation; the investigation of the border between music and silence; the confined yet limitless space of the fragment; and the inspiring and binding strictures of purity.

The book offers two historiographical approaches that can help us deal with the vastness of the twentieth and twenty-first centuries. The first is to adopt a long historical perspective, one long enough to stretch from around 1900 to the present day. The second is to focus on particular topics, like those of the modernist enquiries that I have followed. The two approaches complement each other, as a topical study demands and rewards a broad historical outlook. The former thrives on the act of connection, of revealing how various pieces engage a topic. Such links, as soon becomes apparent, emerge across decades, if not centuries, and genres. For example, the mutable sound worlds opened up by Edgard Varèse have been expanded upon by Kaija Saariaho. I have also discussed how the noise-rock group Sonic Youth explored 
states of sonic flux in ways that evoke Varèse's colliding sound masses. ${ }^{31}$ An account of the enquiry into the fragment can be similarly far-reaching, involving such disparate musicians as Nono, Zorn, Grandmaster Flash, and DJ Shadow. The historical lines sketched in these two examples are chronologically and stylistically longer than the ones that we usually draw. They can also be more surprising and illuminating. To draw them, we need to accept and to adapt to the expanse of the twentieth and twenty-first centuries.

Another way to deal with that expanse is to do what colleagues in other disciplines have done: to focus on particular periods or styles, dividing the centuries into separate categories. Such work, of course, has been done in music scholarship, like that on the Cold War and the cultural turmoil set off around $1968 .{ }^{32}$ We need, though, to do more to establish such areas as defined and independent fields of research, an effort that would not only allow us to unburden ourselves of being specialists in 'a hundred years and counting' of music but also reveal and deepen the rich fields within that 'hundred and some' years. In addition, we should define fields along lines other than chronology or style, like such historical developments as postcolonialism, the sexual revolution, and the emergence of the internet. Once again,

\footnotetext{
${ }^{31}$ David Metzer, 'Sharing a Stage: The Growing Proximity between Modernism and Popular Music', in Transformations of Musical Modernism, ed. Erling E. Guldbrandsen and Julian Johnson (Cambridge: Cambridge University Press, 2015), 100-01.

${ }^{32}$ For scholarship on the Cold War, see the Cold War Study Group of the American Musicological Society, 'Recent Publications', AMS, 25 February 2016, http://ams-net.org/cwmsg/recent-publications/ (accessed 4 May 2017). On the role of new music in the upheaval of 1968, see Beate Kutschke and Barley Norton, eds., Music and Protest in 1968 (Cambridge: Cambridge University Press, 2013).
} 
music scholars have taken up these efforts but we could also draw upon work done in other fields, including critical theory, gender and queer studies, and media studies.

Small, specific periods and long, forking paths of connections are clearly contrasting historiographical models. It is that difference that makes them pertinent to efforts to come to terms with the broad open space of the twentieth and twenty-first centuries. We need many approaches, even disparate ones, to chart that expanse. In fact, the more dissimilar the approaches, the better, as they will give us several historiographical maps. A focus on specific periods puts down chronological markers around which we can orient ourselves, while connecting works engaged with particular topics clears new paths to pursue.

To close, I will return to the pairing between centuries and titles. I may have been surprised to realize that I had relied on centuries in the titles of both of my books, but I am not vexed by it. The book on modernism reveals one way of handling the twenty-first century line, while that on quotation uses the twentieth century as large container, which was needed for a study that dealt with classical, jazz, and pop idioms. As a member of the editorial board of this journal, I know that the editors and board members are increasingly concerned about the pairing of centuries and titles. The journal has incorporated twenty-first-century music and will continue to do so. So should we keep the title or change it?

I would argue that we not worry about it too much. Attempts to periodize or theorize the present are usually short-sighted and too quick to draw lines or wrap things up in period or theoretical boxes. Those boxes seem tight at the time, but they usually spring open and collapse later on as history fills them up with stuff that was not seen or foreseen when the boxes were constructed. Such is the case with theories 
of postmodernism from around the 1980s, as I have argued in my book on modernism. A title, of course, is different from a grand theory. But I would advise caution here as well. We talk about the long eighteenth and nineteenth centuries, so why not the twentieth? Long, of course, will become too long at some point, but we do not have the historical distance to make that decision now. Until then, let us not cut ourselves off from the twentieth century. A new title or historical frame for the journal will emerge in time. Thinking about how we understand and use centuries as categories might just lead us to a title as well as new historical perspectives.

\section{$<$ A $>$ Of the People, by the People, for the People}

\section{$<$ AU >Dai Griffiths}

$<$ Txt $>$ Virginia Woolf's fastidious claim that 'on or about December 1910, human character changed' was always a hard sell for anyone interested or involved in popular music. ${ }^{33}$ Or popular literature: Woolf was discussing, in The Criterion for July 1924, the writer and novelist Arnold Bennett, and included the marvellous observation that the famous change could be seen 'in the character of one's cook', ${ }^{34}$

\footnotetext{
${ }^{33}$ James Hepburn, ed., Arnold Bennett: The Critical Heritage (London: Routledge and Kegan Paul, 1971), 444.

${ }^{34}$ Hepburn, Arnold Bennett, 445.
} 
sure to annoy John Carey, ${ }^{35}$ in whose The Intellectuals and the Masses 'Arnold Bennett is the hero'. ${ }^{36}$

Popular culture was part of what the modernists were avoiding, albeit with knowing nods such as Eliot's 'Shakespeherian rag' in The Waste Land (1922) or Stravinsky's tiny harmonic reference to ragtime (at Fig. $6^{+2}$ ) in the Ragtime for Eleven Instruments (1918). Arnold Schoenberg not only progressed from progressive Brahms but also left behind the tonal world of his Brettl-Lieder (1901) and Verklärte Nacht (1899), this the premise that enabled the journal Nineteenth-Century Music to open in 1977 with the date ' $1 / \mathrm{XII} / 99$ '. ${ }^{37}$ After modernism, postmodernism offered a more inclusive framework but, in a postmodern text par excellence, John Zorn's ‘Snagglepuss', from his album Naked City (1990), fragmented popular music appears and disappears on the strict terms of all-out musical expression, which also has the last and funny laugh.

If the twentieth century's two great 'isms' kept at a distance popular music per se, then certainly one big technological invention was its great enabler for, had Edison taken another hundred years to record his recitation of 'Mary had a Little Lamb', musical scores would have kept coming, generating work for performing musicians, while epic quantities of recorded music would await preservation. At the end of the twentieth century, Soundtrack for the Century on Sony Records included several

\footnotetext{
${ }^{35}$ John Carey, The Intellectuals and the Masses: Pride and Prejudice among the Literary Intelligentsia 1800-1939 (London: Faber \& Faber, 1992), 178-9.

${ }^{36}$ Carey, Intellectuals and the Masses, 152.

${ }^{37}$ Richard Swift, '1/XII/99: Tonal Relations in Schoenberg's Verklärte Nacht', 19thcentury Music 1/1 (1977), 3.
} 
originating moments, or at least presented a great deal of activity, divided into generic types and given originating moments of sorts: if jazz is going to start at some specific time, then its recording just provides one such moment. ${ }^{38}$ Pop music starts with Sousa in 1890, then on to 1911-12 for Gene Greene's 'King of the Bungaloos' and Nora Bayes' 'How You Gonna Keep 'Em Down on the Farm?' Jazz gets going in 1917 (the Original Dixieland Jazz Band followed by Bessie Smith), folk, gospel and blues follows in 1920 (the Fisk Jubilee Singers and Mamie Smith), country in 1923 (Fiddlin' John Carson), R\&B, from doo wop to hip-hop, in 1950 with the Ravens and, finally, rock in 1965 with Bob Dylan, the tacit admission that the Beatles, Kinks, and Rolling Stones, not to mention Elvis Presley and Chuck Berry, all appeared on other record labels. Meanwhile, Broadway starts with Show Boat (1927, in a 1932 recording) while movie music has music for silent films (recorded in 1960) before Cliff Edwards performs 'Singin' in the Rain' in 1929. Sony Classical is a four-CD set divided at 1976, opening with Giuseppe Campanari in Rossini's 'Largo al factotum' in $1903 .{ }^{39}$ However, from the perspective where popular means 'not classical', this set is fascinating, with musical modernism severely selected (Bartok, Stravinsky, Messiaen), and where Pierre Boulez, there only to conduct Ravel in 1975, is only four precarious programming steps from Placido Domingo getting it on with John Denver

\footnotetext{
${ }^{38}$ Sony Legacy 1999, 26 CD, JXK 65750.

${ }^{39}$ Sony Classical: Great Performances 1903-1998. 4 CDs, Sony, J4K 65819, 1999.
} 
six years later. As 'tales from the collapse of the canon', the set could have featured in Robert Fink's penetrating analysis. ${ }^{40}$

Commissioned to write an account of popular music in the West for The New Grove Dictionary (2001), Richard Middleton as historian first presented such a socialconstructivist, technology-determined narrative as 'the main historical shifts', in which the growth of recording was 'extraordinary', but immediately countered with a section entitled 'issues' and the comment - I can hear him speak a phrase like this 'such views seem to allow too little room for other factors, including political struggle and human agency'. ${ }^{41}$ While $c .1900$ was in sound recording a great creator for popular music, it is no doubt the case that digital information has also changed and challenged the recording industry, though whether it is enough to pin down century's end as the great divide is a moot point; even Woolf might have spoken too soon about human character on that score. Too early to tell and, anyway, 'such views seem to allow too little room for other factors, including political struggle and human agency'.

Fink and Middleton I cite for academic readers to nod in sage agreement; John Denver I mention to quite different purpose, essentially for fun, so that I also use

\footnotetext{
${ }^{40}$ Robert Fink, 'Elvis Everywhere: Musicology and Popular Music Studies at the Twilight of the Canon', in Rock over the Edge: Transformations in Popular Music Culture, ed. Roger Beebe, Denise Fulbrooke, and Ben Saunders (Durham, NC, and London: Duke University Press, 2002), 63.

${ }^{41}$ Richard Middleton, 'Popular Music in the West', in The New Grove Dictionary of Music and Musicians, 2nd edn, ed. Stanley Sadie. London: Macmillan, 2001. Version at Grove Music Online, ed. Laura Macy.
} 
'getting it on' instead of 'singing'. I recall Denver on British television a lot in the 1970s and, even at the time, young and head-full of the modernist viewpoint, I could tell he was barely credible: his were songs of sentiment ('you fill up my senses', in his famous song), he thought he was funny and, worst of all, he was located somewhere between pop and American country music and decidedly difficult to pigeon-hole. But John Denver was popular music, make no mistake, and the big leap was to recognize just that: Mitchell Morris's book on the 1970s sees the decade through the lens of Barry White, Dolly Parton, and Cher; and Morris goes outside himself, if you will, to understand the music bottom-up and inside-out. ${ }^{42}$ When I wrote about the elevating modulation recently, it meant a curious deal to make sure that children's television music, the comic song, abandoned 1950s pop recordings, rock music, The Carpenters and Barry Manilow, were all included. ${ }^{43}$ Insofar as that discussion has any consequence for conceptions of periodization, popular music is an attention to the excluded or the oppressed, and starts from its position in culture.

We saw Sony making much of the genres, and David Brackett's book Categorizing Sound will shape how we think about this aspect. ${ }^{44}$ In the academic study of popular music, we now have a happy co-existence of specific musical styles

${ }^{42}$ Mitchell Morris, The Persistence of Sentiment: Display and Feeling in Popular Music of the 1970s (Berkeley: University of California Press, 2013).

${ }^{43}$ Dai Griffiths, 'Elevating Form and Elevating Modulation', Popular Music 34/1 (2015).

${ }^{44}$ David Brackett, Categorizing Sound: Genre and Twentieth-century Popular Music (Berkeley: University of California Press, 2013). 
and places and people, the bustle of academic activity, talking to itself but not necessarily outside itself. 'Popular music' barely exists as a singularity; and maybe that is right. However, Richard Middleton as historian-cum-theorist really did attempt an overview in Voicing the Popular, and the book's muted reception - no reviews in TCM or Popular Music, for example - suggests on slim evidence that people preferred to pretend that Middleton's endeavour had not happened and to carry on regardless. ${ }^{45}$ David Hesmondhalgh, who did review it in detail, provocatively and assiduously, sounded like Joe Strummer on an early Clash single when he sneered that 'a copy should be forced into the hands of every over-productive researcher with nothing of any substance to say'. ${ }^{46}$ Middleton's book is 'on the subjects of popular music', starts with a poem-become-song published in 1856, but soon swings inclusively back to Mozart's Magic Flute in 1791; he ends the book watching Buena Vista Social Club (1997) but earlier, and nearer his publication date, gets cross with 'bling rapper 50 Cent and Tory boy band Busted'. ${ }^{47}$ The book effectively defers or complicates any finality or certainty, assuredly not pinned down to dates, then, now, or in time to come.

${ }^{45}$ Richard Middleton, Voicing the Popular: On the Subjects of Popular Music (New York: Routledge, 2006).

${ }^{46}$ David Hesmondhalgh, 'Review of Richard Middleton Voicing the Popular', Journal of Popular Music Studies 21/3 (2009), 320.

${ }^{47}$ Middleton, Voicing the Popular, 1, 6, 244, 24. 
For the issue of 2000 as a dividing line, then, my conclusion heads in two opposed directions. Pragmatically, and taking Soundtrack for a Century as cue, there is enough matter between those dates, including in popular music so-called, to occupy an academic journal named for its temporal boundary. Economies of fragmentation lead the way: where Rock Music Studies is now found, so surely will the Hip Hop Yearbook, Punk Theory Online, and the International Review of Heavy Metal Studies. Against or alongside that novelistic vision, popular music, or its study, has no particular stake or interest in 1900-2000 as specificity, but exists as a complex construct: its 'popular' is, among many other things, a way of thinking about people, its study instinctively theoretical and historical. A corollary to this dichotomy might reasonably turn on the question of what a journal is there for, and I like to think that Richard Middleton offers a signal in, of all places, his acknowledgements, just before thanking Jane Middleton. Through the footnote and bibliography, as emblems of 'interconnections and dependencies' the book, in itself, shows that 'our lives actually contain important pockets and models of socialistic practice. To adapt Marx: we may not know it but we are doing it.' 48 'Acknowledgements' they may be, but they describe ways of working and ways of living. We speak of popular music, as a people's music, to other people, real people in a real world.

\section{$<$ A $>$ Critiquing 'Twentieth-Century Music': A Polyvocal Ethnomusicological}

\section{Response}

\section{<AU>Laudan Nooshin and Griff Rollefson}

\footnotetext{
${ }^{48}$ Middleton, Voicing the Popular, viii.
} 
$<$ Txt $>$ In order to think about the stories, people, events, and musics that animate a thing called 'the twentieth century' we must first examine our own layers of privilege. ${ }^{49}$ Eurocentrism and its twentieth-century myopia have conspired to naturalize a universal idea of human progress at the expense of other parallel histories. As one commentator has put it, 'there is no longer a mainstream view ... with several "other," lesser important cultures surrounding it. Rather there exists a parallel history which is now changing our understanding of our transcultural understanding. ${ }^{50}$ For these reasons we have sought to respond to this forum's brief by mobilizing a polyvocal account from the perspective(s) of ethnomusicology, shaped by viewpoints of over a dozen scholars and scholar-practitioners who agreed to act as respondents for this investigation. ${ }^{51}$

As an invited Associate Editor for Twentieth-Century Music in its founding stages and for the first ten years of its life, I [LN] was drawn to the journal's ambition to 'engage with the full breadth of musical activity in the twentieth century' and to go

${ }^{49}$ See Walter Johnson, 'On Agency', Journal of Social History 37/1 (2003).

${ }^{50}$ Gallery Brochure, 'The Hybrid State Exhibit', Exit Art, 578 Broadway, New York (2 November-14 December 1991), as cited by Anne McClintock, 'The Angel of Progress: Pitfalls of the Term "Post-Colonialism", Social Text 31/32 (1992), 84.

${ }^{51}$ We would particularly like to thank Henry Stobart, Sue Miller, Stephen Wilford, Andrew Green, Hettie Malcomson, Anna Morcom, Maria Mendonca, Byron Dueck, Abigail Wood, Thomas Hilder, Mohsen Mohammadi, Amir Eslami, and Deborah Wong. 
beyond the often artificial and limiting boundaries of genre, geography, culture, and so on; in other words, to be a journal for all musics. ${ }^{52}$ In fact, despite its laudable aims and with some notable exceptions, the journal has largely attracted submissions focused on Euro-American art music, with certain kinds of music particularly well represented. ${ }^{53}$ Perhaps it was inevitable that ethnomusicologists might not have felt that a journal bearing a title with such established associations was for them. The journal's very raison d'être is largely predicated on the normative assumption that one particular historical periodization is universal. Clearly, while it did gain a strong global presence - largely through the impact of colonialism and its ongoing repercussions - there are many peoples, cultures, and musics for whom/which very different notions of periodization are significant. An explicit acknowledgement of the cultural specificity of the title might have signalled a recognition both of different histories and ways of thinking about history and the often invisible (in this case, postcolonial) power structures that sustain singular historical narratives, which tend, in respondent Andrew Green's words, to ‘exclude unfamiliar histories', and which we

\footnotetext{
${ }^{52}$ The quotation is taken from Allan Moore and Christopher Mark's original proposal for the journal (unpublished communication to CUP, c. 2001).

${ }^{53}$ For GR, among those laudable aims and notable exceptions was the invitation in 2011 to review Martin Munro's book Different Drummers, which, it turned out, was about neither the twentieth century nor music per se, but was nonetheless an important book for ethno/musicologists working on the twentieth century. See J. Griffith Rollefson, 'Review of Martin Munro, Different Drummers: Rhythm and Race in the Americas', Twentieth-Century Music 10/1 (2013).
} 
arguably perpetuate when we participate in the discourse.$^{54}$ As Stephen Wilford, another respondent commented, 'I cannot escape the sense that imposing a clear distinction between the musics of the twentieth and twentieth-first century only serves to further privilege Euro-American notions of history and time. ${ }^{55}$

Most of those we spoke to did not find the distinction between twentieth- and twentieth-first-century musics particularly useful. One correspondent signalled the need for an awareness of 'continuity and disjuncture in musical practice ... [M] usic continues to be practised around the globe and musical agents (scholars included) think about contemporary practices in relation to preceding ones, both recent and more distant. ${ }^{56}$ For Wilford, 'the explosion of internet access around the millennium appears set to create a radical shift in the speed at which musics flow from Europe

${ }^{54}$ Personal communication with Andrew Green (December 2016), who went on to suggest that 'no sub-discipline of music studies is quite so well-equipped to engage in a serious and nuanced way with how different understandings of time, era, epoch, and so on are perpetuated in the process of music-making ... We spend time with people for whom these categories matter, and who sing about or reflect affective senses of different times and eras in their music. I was in Mexico in December 2012, when the Mayan Long Count calendar was due to run out, and some of the musicians I was working with were clearly emotionally engaged with all the eschatological covfefe surrounding that event.'

\footnotetext{
${ }^{55}$ Stephen Wilford, personal communication (January 2017).

${ }^{56}$ Anon., personal communication.
} 
and Northern America to the rest of the world throughout the twenty-first century'. He continues, 'As an ethnomusicologist, I feel it is vitally important to ... critically assess the power relations that internet technologies embody. ${ }^{, 57}$

As other respondents noted, there are historical turning points but these are highly positional and contingent rather than universally experienced. For Thomas Hilder, 'historiography is dependent on multiple factors like place, region, religion, race, class, gender, sexuality, ability ... One way in which I can see there might be an obvious a shift is owing to the rise of digital media, which for me happened literally around the year 2000 though again this turning point might have been felt more or less abruptly at different times depending on those different categories.' 58 Technological change was, unsurprisingly, a constant theme. For Henry Stobart:

$<$ Ext $>[0]$ ne big difference between the two centuries ... derives from digital technology and its impact on intellectual property. I connect the twentieth century with the rise of music recording, where documenting music as sound was a key aspect of what ethnomusicologists did. I now find myself working with people - often from very humble backgrounds - who are able to make recordings of themselves ... Ironically, at the same time, immense amounts of material are being posted online ... This juxtaposition of extending copyright protection and clamping down on infringement, side by side with the free flow of music (especially online, but also through e.g. optical disc piracy) has created

\footnotetext{
${ }^{57}$ Wilford, personal communication.
}

${ }^{58}$ Thomas Hilder, personal communication (January 2017). 
a situation that feels rather different from the last century. ${ }^{59}$

$<$ Txt $>$ Notwithstanding the imperative to allow for different periodizations, there are indeed examples around the world where musical cultures underwent significant changes close to the turn of the millennium. In Iran, for instance, the election of reformist President Mohammad Khatami in 1997 coincided with the arrival of the internet, resulting in considerable impact (albeit wholly unrelated to the 'millennium factor' or the Gregorian calendar) ${ }^{60}$ Iranian ethnomusicologist Mohsen Mohammadi observes that

$<$ Ext $>[t]$ he end of the second millennium became a turning point for the classical/urban/art music of Iran. It happened that the last generation of the millennium were the pioneers of Persian classical music trained through the national identity movement in the last decade of the Shah's reign ...

Accidentally, this shift happened just around the year 2000 ... I expect the

\footnotetext{
${ }^{59}$ Henry Stobart, personal communication (December 2016).

${ }^{60}$ In fact, the year in Iran was not 1997 but 1376, according to the Iranian solar calendar. This calendar is based on the pre-Islamic Zoroastrian calendar and begins on the spring equinox (with year 0 dated to the Prophet Mohammed's migration to Medina in $622 \mathrm{CE}$ ). It is worth noting that both the Gregorian and the Arabic solar hejri calendars are used in Iran. Stephen Wilford also comments: 'As someone whose work focuses upon music in predominantly Islamic societies, I feel that we need to acknowledge non-Christian calendars (Islamic, Chinese, etc.) and wonder to what extent a focus upon the millennium places false emphasis upon the neat categorization provided by "Western" notions of history.'
} 
Persian year 1400 to be a turning point for Iranian society and music. ${ }^{61}$

$<\mathrm{Txt}>$ The above points lead to a second area of discussion concerning the relationship between historiography and ethnography, described by Philip Bohlman as the tension between 'music as temporal and historical phenomenon and music as a geographical and cultural phenomenon'. Bohlman points out that while 'many ethnomusicologists and historical musicologists have striven to resolve their approaches to the time-place disjuncture ... it still remains an open question as to whether music history and music ethnography address the same metaphysical conditions in music'. ${ }^{62}$ Thus, many of our ethnomusicologist respondents expressed their initial confusion about the temporal focus of the journal and continued reservations about publishing in a journal that had an ostensibly historical remit. ${ }^{63}$

${ }^{61}$ Mohsen Mohammadi, personal communication (January 2017). Mohammadi added that: 'The beginning of the 21 st Century was the rise of the baby boomers of Persian classical music. Moreover, the function and use of Persian classical music changed; it was no longer an entertainment for the elderly or intellectuals. Several musicians used the same instruments and music to express their themes for their young fans.'

${ }^{62}$ Philip V. Bohlman, 'World Music at the "End of History”, Ethnomusicology 46/1 (2002), 6 .

${ }^{63}$ In the words of one, anonymous respondent (December 2016), 'I wondered whether [the journal] would be an appropriate site for work done on music of the present day ... As we get further into the century, ethnomusicologists will be less and less likely to think of $t \mathrm{~cm}$ as a place to publish or place to look for articles relevant to their 
The question of whether ethnography and the study of music history are mutually exclusive is an important one. Arguably, ethnography can never be solely of the 'present'. As Sue Miller, another respondent, wrote:

$<$ Ext $>$ The merging of music history and fieldwork research is a complementary one for me and I am always moving from the present to the past to the future particularly as I engage with musicians' accounts of the past and the present, with the analysis of recorded music (usually from the 1920s to the present) and with live performance. Defining twentieth-century or twenty-first century music would be an impossible task, particularly if you take a wider, non-Anglocentric postcolonial view (and there's still a long way to go before women feature more equitably or where popular musics in other languages/from non-Western cultures receive the same level of dedicated and detailed scholarship for example as those genres with more status). ${ }^{64}$

$<$ Txt $>$ Wilford questions whether

$<$ Ext $>$ this division between centuries might privilege linear ideas of 'progress' ... Do we risk viewing the twenty-first century as something new and innovative, whilst failing to comprehend the intricate, and often messy, ways in which the past and present interact? The role of traditional and folk musics, in both old and new forms, seem to problematize our understandings of history, and the recycling of musics and musical ideas in new ways continually

work.'

${ }^{64}$ Sue Miller, personal communication (December 2016). 
complicate notions of historical change and development. ${ }^{65}$

$<$ Txt $>$ For Sam MacKay, the question remains as to whether 'this kind of metaperiodization is to be challenged rather than participated in: 1989, 2001, 2008, 2011 and 2016 are just some of the years regularly declared as the 20th century's end-point, usually with a highly partial and ideologically convenient view of history in mind' ${ }^{66}$

It seems that such periodizations tell us more about our own biases, blindspots, and agendas than anything else. Indeed, as Deborah Wong so forcefully reminded us when she 'left music' at the Society for Ethnomusicology's annual meeting in 2012, the very idea of 'music' is an ideologically and historically fraught construct. As both discourse and practice, she argued, 'music' today acts as a

${ }^{65}$ Wilford, personal communication (January 2017).

${ }^{66}$ MacKay, personal communication (January 2017). On GR's view, ethnomusicology's 'short twentieth century' ended around 1991 as scholars began to consider more critically the constructedness of both our field and our 'fields' in the wake of geopolitical realignments. The idea of the short twentieth century was first proposed by Hungarian historian Iván T. Berend and elaborated in Eric J. Hobsbawm's The Age of Extremes: The Short Twentieth Century, 1914-1991 (London: Michael Joseph, 1994). Looking to the future of the journal, Sue Miller commented: 'If I had to come up with a new title, I might call the journal Music 20/21 and follow that with a short paragraph discussing its focus, where a more nuanced view of music in the last 116 years could be discussed' (personal communication, December 2016). 
solipsistic and depoliticizing buffer that 'contains the very terms for our unimportance and irrelevance':

$<$ Ext $>$ Music can't matter and those who focus on it can't matter either due to a long, post-Enlightenment ideological process casting music as the feminine corner of the humanities; feelingful, experiential, embodied. And ethnomusicology is the feminine corner of music scholarship, because it is feelingful, experiential, and embodied ... If we want our work to matter, we must de-link, I think, not rescue, de-link our work from music as a historical and ideological construct. ${ }^{67}$

$<$ Txt $>$ Ultimately, the questions raised by this forum, and by the journal's title, should lead us to remain conscious of whose history is rendered visible or audible through 'twentieth century' discourse, what ideological work we perform when we study 'music', and therefore, whose stories - whose voices - we privilege.

\section{<A>Towards a Relational View of Twentieth-Century Music}

\section{$<$ AU>Hon-Lun Yang}

$<$ Txt $>$ Self-identified as 'plural' and embracing 'difference', the journal TwentiethCentury Music aspires not to 'exclude any style/genre/category/use of twentiethcentury music'. Its publications seek to convey a 'sense of the diversity of musical practice' and 'to create the very frameworks through which we think a period of

${ }^{67}$ Deborah Wong, Remarks at the 2012 SEM President's Roundtable on Music and Power (New Orleans, 2012), later published as Deborah Wong, 'Sound, Silence, Music: Power', Ethnomusicology 58/2 (2014). 
musical history that has yet to be defined' ${ }^{68}$ However, a rough statistical count of the subjects of articles published here between 2004 and 2015 is revealing. Approximately 50 per cent are on single composers and works, of which four-fifths are European and one-fifth American; 10 per cent of articles are on popular music, half of which focus on European and half on American music; 35 per cent address various aspects of Western music and related issues; fewer than 5 per cent are on music outside the West; ${ }^{69}$ and nearly all contributors appear to be of Western descent. If the figures do speak for themselves, the notion of 'twentieth-century music' represented in the journal is 'music of the West' as discoursed by largely Western writers, for a mostly Western audience. In fact, a similar geographic limitation is also evident in non-Western writers' understanding of the term. For instance, some sixty Chinese journal articles that refer to twentieth-century music (ershi shiji yinyue) in their titles are all on Western art music. ${ }^{70}$

\footnotetext{
${ }^{68}$ David Clarke, 'Editorial: Twentieth-Century Music - Plural', Twentieth-Century Music 1/2 (2004), 155; Christopher Mark and Allan Moore, 'Editorial', Twentieth-Century Music 1/1 (2004), 3; Robert Adlington and Julian Johnson, 'Editorial', Twentieth-Century Music 11/1 (2014), 3 and 4.
}

${ }^{69}$ These articles, detailed in the bibliography, are by Katherine Butler Brown, Amelia Maciszewski, John Morgan O’Connell, and Miki Kaneda. Two further articles, on issues pertinent to relationship of Western music and non-Western music in reception and transcription, are by Anahid Kassabian and Jann Pasler. Naturally how 'West' is defined can be problematic, and I simply treat both Europe and America as 'the West'.

\footnotetext{
70 These articles by Chinese scholars were retrieved from the China Academic Journals Full-text Database: http://oversea.cnki.net/kns55/brief/result.aspx?dbPrefix=CJFD (accessed 8 January 2017).
} 
'Twentieth-century music' is not a monopoly of the West, so why is the use of the term so geographically restricted? As Michel Foucault points out, 'in every society the production of discourse is at once controlled, selected, organized and redistributed according to a certain number of procedures, whose role is to avert its powers and its dangers, to cope with chance events, to evade its ponderous, awesome materiality'. ${ }^{71}$ Foucault also argues that prohibition comes in different forms, including the privileged or exclusive right to speak of a particular subject, which interacts with other forms of prohibitions. ${ }^{72}$ Humans' will to knowledge, as he understands it,

$<$ Ext $>$ like the other systems of exclusion, relies on institutional support: it is both reinforced and accompanied by whole strata of practices such as pedagogy - naturally - the book-system, publishing, libraries, such as the learned societies in the past, and laboratories today ... [T]his will to knowledge ... tends to exercise a sort of pressure, a power of constraint upon other forms of discourse. ${ }^{73}$

$<$ Txt $>$ I do not mean to suggest that this journal's limited geographical reach is a sign of knowledge prohibition; but such a phenomenon does reveal a certain relationship between the West and its others. As a number of scholars have pointed out, such a relationship is manifested in various forms of domination - musically,

\footnotetext{
${ }^{71}$ Michel Foucault, 'The Discourse on Language', in The Archaeology of Knowledge, trans. Rupert Swyer (New York: Pantheon Books, 1971), 216.

${ }^{72}$ Foucault, 'The Discourse on Language', 216.

${ }^{73}$ Foucault, 'The Discourse on Language', 219.
} 
through borrowing, representation, and appropriation; and sociopolitically, through imperialism, colonialism, and globalization. ${ }^{74}$ Added to this list is the tendency for many musicologists not to see what is beyond music's 'Western' intellectual, cultural, and musical boundaries - not recognizing music's capacity to move from one place to another, not only materially but also conceptually, as a non-human agent that fosters human contact and exchanges in many different forms for many different reasons.

Let us consider the example of China, whose musical tradition went through radical transformations in the twentieth century. ${ }^{75}$ China is now a country with probably the highest number of children learning to play a Western instrument, with thousands of them pursuing professional musical training at home and abroad. ${ }^{76}$ There are eleven stand-alone music conservatories and many more affiliated with education universities and other arts institutes in the PRC, Taiwan, and Hong Kong. Concert halls and opera theatres as well as professional orchestras are emerging in major

\footnotetext{
${ }^{74}$ See Georgina Born and David Hesmondhalgh, eds., Western Music and Its Others: Difference, Representation, and Appropriation in Music (Berkeley: University of California Press, 2000); and Timothy Taylor, Beyond Exoticism: Western Music and the World (Durham, NC: Duke University Press, 2007).

${ }^{75}$ See the bibliography for details of my own writings on various aspects of China's multifaceted soundscape.

${ }^{76}$ As reported by representatives from German conservatories and American music schools at the 2016 CHIME Workshop on 'Music Education in China' held in Hamburg, the proportions of Chinese students registered in their music programmes were quite high.
} 
Chinese cities. ${ }^{77}$ The two best-known contemporary music festivals are the Beijing Modern Music Festival (which started in 2002), and the Shanghai Conservatory New Music Week (which started in 2008). Most of all, Chinese composers' works are now a part of the Western music repertoire; for instance, Chinese composer Bright Shang's opera Dream of the Red Chamber was premiered by the San Francisco Opera in September 2016; and Chinese composers such as Tan Dun, Chen Qigang, Zhou Long, Chen Yi, Guo Wenjing, and Wang Xilin are names not unfamiliar to Western audiences of contemporary music. ${ }^{78}$

But hardly any of this is reflected in this journal or in twentieth-century music historiography. ${ }^{79}$ China is not alone in its absence; so are other Asian countries and countries outside central Europe and the US. The Cambridge History of TwentiethCentury Music is an exception, the editors showing a degree of awareness of musical practices outside the West. The volume's multi-author approach, as Nicholas Cook and Anthony Pople point out in their introduction, does not present a uniform narrative, but instead 'a series of complementary, sometimes overlapping, and often competing histories that reflect the contested nature of interpretation' ${ }^{80}$ In a way,

\footnotetext{
${ }^{77}$ Shanghai led such a trend with the opening of its Grand Theatre in 1998, while Beijing's National Center for Performing Arts was opened in 2007, followed by the Guangzhou Opera House in 2010.

${ }^{78}$ These composers' names are presented last name first according to the Chinese practice.

${ }^{79}$ A case in point is Richard Taruskin, The Oxford History of Western Music (Oxford: Oxford University Press, 2005); and likewise Auner, Music in the Twentieth and Twenty-first Centuries.

${ }^{80}$ Nicholas Cook and Anthony Pople, eds., The Cambridge History of Twentieth-Century Music (Cambridge: Cambridge University Press, 2004), 3.
} 
these complementary and competing histories of twentieth-century music should be the paradigm for those of the twenty-first century, particularly at a time of profound and difficult changes across the world. ${ }^{81}$

If we agree that discourse is indicative of what is deemed important, and that it reinforces the knowledge that builds a society's belief system, the West's narrative of the music of the twentieth century entrenches a Western or Eurocentric worldview that overlooks music's power to connect and to reach out. Hence, I propose a relational view of twentieth-century music. 'Relational' is a term I borrow from Georgina Born and Nicholas Cook. ${ }^{82}$ Born uses it to advocate interdisciplinary music scholarship, whereas Cook uses it to explicate musical encounters evident in musical representation through notation and analyses. I use the term to refer to music's relational geography, that is, how music 'travels' in many ways, resulting in many forms of cross-cultural fertilization of musical activities, ideas, and compositions worldwide. Two projects I have recently been involved in serve to illustrate what I mean by relational music geography.

${ }^{81}$ In my view, this approach of providing complementary and competing histories of twentieth-century music is the embodiment of pluralism. As Richard Ashcroft and Mark Bevir have argued, while mismatched cultural pluralism may have caused the current political situations in the UK and elsewhere, it can also be the solution. See their 'Pluralism, National Identity and Citizenship: Britain after Brexit', The Political Quarterly 87/3 (2016), 355.

${ }^{82}$ Georgina Born, 'For a Relational Musicology: Music and Interdisciplinarity, Beyond the Practice Turn: The 2007 Dent Medal Address', Journal of the Royal Musical Association 135/2 (2010); Nicholas Cook, ‘Anatomy of the Encounter: Intercultural Analysis as Relational Musicology', in Critical Musicological Reflections: Essays in Honour of Derek B. Scott, ed. Stan Hawkins (Farnham: Ashgate, 2012). 
In research on Russian émigré musicians and musical life in Shanghai in the interwar-period of the last century, Simo Mikkonen, John Winzenburg, and I traced the prosperous Western musical scene in China back to the activities of Russian musicians there in the 1930s and 1940s. These musicians not only contributed to Shanghai's cultural life then but also have an impact on China's soundscape now. Russian musicians such as Boris Zakharov and Vladimir Shushlin who taught at the National Conservatory of Music (now the Shanghai Conservatory of Music) trained the first generation of renowned Chinese pianists, singers, and composers who became music leaders at various conservatories in China in the second half of the twentieth century. Further, Russian émigré composers Alexander Tcherepnin and Aaron Avshalomov, as a result of their contacts with Chinese musicians and culture, served as inspirations for Chinese composers, helping to put Chinese music on the map of twentieth-century music. ${ }^{83}$

China's musical connectivity to the West is explored from a wider perspective in an essay collection China and the West: Music, Representation, and Reception, which I co-edited with Michael Saffle. ${ }^{84}$ Seeing 'music' - broadly defined - as an agent for identity, ideology, diplomatic relations, etc., the twelve authors probed musical encounters between China and the West, such as early missionaries' efforts in building the organ in China, the transculturation of the first Western symphony

\footnotetext{
${ }^{83}$ See Hon-Lun Yang, Simo Mikkonen, and John Winzenburg, Networking the Russian Diaspora: Russian Musicians and Musical Activities in Interwar Shanghai (Honolulu, Hawaii: University of Hawaii Press, forthcoming).

${ }^{84}$ Hon-Lun Yang and Michael Saffle, eds., China and the West: Music, Representation, and Reception (Ann Arbor: University of Michigan Press, 2017).
} 
orchestra to become a Chinese institution, the sinicization of Western musical genres in the hands of Chinese composers, the musical rendition of 'Chineseness' by Western composers in their intercultural theatrical works, and the meanings of 'Chineseness' to Chinese versus Western composers and audiences. ${ }^{85}$

In fact, this relational approach to music is on the rise. At a chapter meeting of the International Musicological Society in Hong Kong in 2015, Nicholas Cook called for 'a musicology of interconnectedness' that combines 'local perspectives with global awareness ${ }^{86}$ I myself attended a couple of further events that embraced such a 'relational' awareness: a workshop on popular music held at the University of Chicago's Beijing Center in $2014 ;{ }^{87}$ and a symposium on intercultural compositions by Asian as well as Western composers at the University of South Florida in $2015 .{ }^{88} \mathrm{I}$ am also aware of an ongoing project on the global transmission and adaptation of 'Le

\footnotetext{
${ }^{85}$ The volume includes a detailed bibliography on intercultural compositions, particularly SinoWestern works.

${ }^{86}$ The abstract of Cook's paper 'Toward a Global Musicology?' is available at http://media.wix.com/ugd/8cee38_97713e6a8bea468a8a212c479a7770f5.pdf (accessed 19 March 2017).
}

${ }^{87}$ The workshop resulted in Michael K. Bourdaghs, Paola Iovene, and Kaley R. Mason, eds., Sound Alignments: Popular Music in Asia's Cold Wars (Durham, NC: Duke University Press, forthcoming), to which I contributed the chapter 'Cosmopolitanism and Sound Alignments: Cantonese Cover Songs from Hong Kong Films of the 1960s'.

${ }^{88}$ The event entitled 'USF Composition in Asia International Symposium and Festival' was held on 22-5 January 2015: http://music.arts.usf.edu/compositioninasia/ (accessed 19 March 2017). 
Fantôme de l'Opéra' led by Cormac Newark that involves scholars from the US, UK, Italy, Germany, Brazil, and Hong Kong. ${ }^{89}$

The twentieth century was a period when music's circuitry expanded significantly because of human migration and technology, resulting in musical dialogues of different forms among different peoples from different parts of the world. ${ }^{90}$ Given this, it is timely to revisit the geographical scope of the music covered in this journal. Quite likely in the future, historians and scholars will trace many of the new musical trends in the twenty-first century back to the previous one. One of these trends will no doubt be musical interculturality and plurality. Thus, if TwentiethCentury Music embraces 'all aspects of music in the long twentieth century' as the journal indicates in its instructions for contributors, it becomes imperative to expand its scope and geography by viewing music relationally.

\section{<A>Defining South African Musical Arts Practices: A Brief Chronicle of the Twentieth and Twenty-first Centuries}

\section{$<$ AU >Ndwamato George Mugovhani}

\footnotetext{
${ }^{89}$ Newark and some of his project collaborators gave a workshop entitled 'The Phantom on Film: A Roundtable' at the University of Hong Kong in 2017.

${ }^{90}$ Circuitry is a term I borrow from Andrew Jones's paper 'Circuit Listening: Grace Chang and the Chinese 1960s', presented at the Research Colloquia of the University of Hong Kong, 2011: www.music.hku.hk/events/colloquia/rc46.html (accessed 19 March 2017). This paper is part of Jones's book Circuit Listening: Chinese Popular Music in the Transistor Era (Minneapolis: University of Minnesota Press, forthcoming).
} 
$<\mathrm{Txt}>$ South Africa is a country that has, relative to much of the rest of Africa, found its independence from white rule only fairly recently. Its outlook during the apartheid era was more reflective of the Western than the African world, and its historical narratives still present Eurocentric perceptions. The colonialist missionary enterprise, and the resultant encroachment of Western idioms and cultural elements, saw a breakdown of indigenous knowledge systems. Only recently, since the advent of democracy in 1994, do we find some urgency to put forth the African worldview - a task that is tackled from different disciplines; and mine is an African musicological perspective.

From such a perspective, the question of what constitutes twentieth- or twenty-first-century music has to be seen in the light of these colonial and postcolonial conditions. What can be said is that, since around the beginning of the year 2000, the primary objective in South African performative culture has changed: there has been a shift in the relations between cultural heritage practices and people's sociopolitical objectives and identities. To illustrate the point, this essay considers three contrasting musical practices: indigenous music, choral music, and jazz and popular musics. Each of these case studies provides its own glimpse into South Africa's negotiation with the colonialist and postcolonialist situation and its connections with the wider world.

Indigenous African cultural practices in general have undergone shifting identities with regard to patronage and social and political allegiance. This could be attributed to changes in contemporary social and economic patterns of life. Institutions have changed and so have performative traditions. Whereas indigenous African music used 
to be mainly associated with ceremonies, rituals, socialization, and entertainment, some of these traditional musical practices have now developed and are manifesting new identities. For example, the Tshikona song and dance genre, traditionally a preserve for males, has been appropriated and fashioned for all-gender participation; there are indeed women-only Tshikona ensembles. ${ }^{91}$ The exclusive royal custodianship of such cultural practices has also been challenged. Tshikona ensembles are now frequently deployed by anybody as a space for the articulation of power. ${ }^{92}$

Until recently in the twenty-first century, there had been no hope that the practitioners of an indigenous African music genre could ever derive a living out of their art. There was also fear that some of the indigenous musical practices were becoming extinct because the few practitioners still available were of advanced age and on the brink of death. Responding to this eventuality, some contemporary musicians, albeit without formal training, are attempting to preserve indigenous cultural heritage by trying to stimulate the original musical creations of their forebears. The archive- or museum-frozen original African music collections are

${ }^{91}$ See Jaco. H. Kruger, 'Contemporary Changing Socio-economic Patterns in Venda Cultural Practices', paper presented at the Travelling Institute Research Seminar. Thohoyandou, University of Venda, 2002.

${ }^{92}$ George, N. Mugovhani and Daniel T. Tshishonge, 'Shifting Identities in South African Indigenous Cultural Practices: A Case Study of Tshikona and Tshigombela of Vhavenda Communities in Limpopo', South African Journal of Folklore Studies 22/2 (2012). 
being rejuvenated by arrangements, re-compositions, and score-based creations performed by modern pop bands, by artists such as Marcus Mundalamo and Naledzani Netshirembe, and by other instrumental and/or vocal ensembles such as the Soweto String Quartet.

Despite their use of non-African instruments, popular musicians in Africa have managed to use new source materials while sustaining their defining stylistic traits of the original indigenous music and dance compositions..$^{93}$ This could be seen as an emerging form of syncretism. The country has also seen an opening up of a global village through the allocation of space and resources to indigenous music practitioners to create new works. South Africa has recently witnessed artists such as Ntshengedzeni Mamphodo collaborating with the Cuban/Spanish international musician Omar Sosa to record and produce an enthralling syncretized album for release in $2017 .{ }^{94}$

Popular music incorporating traditional genres, then, has begun to function within the sociocultural and religious lives of today's South Africans; it is no longer regarded as 'foreign' to the concert hall. It is frequently encountered in music shops both in rural and urban areas. Hence, even though the essence of indigenous African

\footnotetext{
${ }^{93}$ George N. Mugovhani, 'Emerging Trends from Indigenous Music and Dance Practices: A Glimpse into Contemporary Malende and Tshigombela', The Southern African Journal for Folklore Studies $25 / 1(2015)$

${ }^{94}$ George N. Mugovhani, and Lebohang L. Nawa, 'The Socio-economic Challenges of South African Indigenous Musicians: A Case Study of Venda-based Vho-Ntshengedzeni Mamphodo', The Southern African Journal for Folklore Studies (in press).
} 
music has hardly changed, attitudes towards it have developed, and musical practices have witnessed significant evolution on South Africa's rapidly changing postcolonial terrain.

On the choral front, composers have been trying in many ways to integrate their Africanness into their creative oeuvre. From the 1950s, when black South African nationalism flourished, a strong agenda to Africanize choral work emerged. This was evidenced by the work of composers such as Tiyo Soga, John Knox Bokwe, and Enock Sontonga through that of Polumo Mohapeloa, Reuben Caluza, J. S. P. Motuba, Michael Moerane, and Mzilikazi Khumalo. ${ }^{95}$ One way these composers recaptured their Africanness was to follow the actual speech rhythm of their respective languages, mostly remaining close to stylistic traits common to a typical African melody. Their mission was to consciously establish, pioneer, and promote indigenous African choral culture. ${ }^{96}$ The latter part of the twentieth century also saw a new generation of choral music composers, such as Mfanufikile Chonco, Christian Ncgobe, and Phelelani Mnomiya, who continue to find ways to incorporate

\footnotetext{
${ }^{95}$ George N. Mugovhani, 'Venda Choral Music: Compositional Styles' (doctoral thesis, University of South Africa, 2008).

${ }^{96}$ George N. Mugovhani and Ayo Oluranti, 'Symbiosis or Integration: A Study of the Tonal Elements in the Choral Works of Mzilikazi Khumalo and Phelelani Mnomiya', Muziki Journal of Music Research in Africa 12/2 (2016). See also <insert reference to Mugovhani (1998) here>
} 
indigenous resources into choral compositions that combine both traditional African and Western idioms. ${ }^{97}$

Unlike in the previous era when white choirs and black choirs functioned as separate entities, each concentrating on music of their respective mother tongues, the twenty-first century has seen the emergence of choral musicians of all races coming together to perform both African and Western choral works. Lately South Africa has enjoyed mass choirs comprising people of white, black, and other races, accompanied by Western orchestras and/or African instruments in venues that are no longer demarcated, and on television and other media. The previously white-only Drakensberg Boys Choir now has young black choristers, and this outfit has travelled globally, representing the South African 'rainbow nation' in terms of demographics and repertoire.

South African composers have not yet managed to totally shed the influence of Western traits. Continuing globalization could be one of the reasons why Western elements are still embraced in contemporary black compositions and arrangements. The degree of creativity available in combining these idioms within an intercultural framework is suggestive; and contemporary composers are pushing stylistic and structural boundaries to achieve a strong African identity. The South African choral genre is bound to evolve as a unique and perhaps independent choral product in the global market. It is up to current and subsequent generations to pursue this trend and eventually to produce new genres and forms of South African indigenous choral music that would lead to a recognizable South African music identity.

\footnotetext{
97 Yvonne Huskisson, 'Southern Africa’s Contemporary Black Composers', Lantern 43 (1994), 37.
} 
South African popular music owes much of its character to African American music. For sociopolitical reasons, the African American experience resonated with black South Africans. Accordingly during the 1940s up to the 1960s, South African jazz, an art form that borrowed from America, became popular in South Africa. ${ }^{98}$ In the 1970s jazz was still regarded as an art that did not belong in the classroom (and in any case there was a scarcity of formal education for the black population of South Africa). Its practitioners learnt from practising for long hours, figuring out how the notes worked and how to perfect their instruments. Jazz was taught at homes, in the communities, and by association with the idols. According to bassist Victor Masondo, trumpet player Prince Lengoasa, and many others, music mostly started within the family; thereafter it devolved to the church. ${ }^{99}$ The most distinguishable traits of this art form were marabi, ragtime, and swing embodied by musicians such as Kippie Moeketsi, Abdullah Ibrahim, Hugh Masekela, Jonas Gwangwa, and Miriam Makeba.

98 Tiisetso Makube, 'Our Kind of Jazz Post-1994', Jazz Life: South Africa's Definitive Jazz Guide 1/1 (2013).

${ }^{99}$ Joe M. Malinga, 'Towards Realisation of South African Jazz Assuming Its Rightful Place in the Cultural Identity and Heritage of the Country' (MA diss., University of Venda, 2013). 
According to Chats Devroop, just as jazz was viewed as a separate music of the developed ghetto in America, it became a means of segregation in South Africa. ${ }^{100}$ The apartheid regime gave space to classical and the so-called advanced art by providing state support, but not to jazz. Denying jazz's acceptance into mainstream education and having its performances and spaces and public strictly controlled constituted a form of banning; South African jazz became a popular voice of the oppressed. ${ }^{101}$ Most South African jazz musicians of the time eventually decided to go into exile in order to sustain their careers. ${ }^{102}$ This was one of the defining factors of the state of jazz in twentieth-century South Africa. The void was later filled by mbhaqanga and disco, which later became known as 'bubblegum' music because of its short popularity span. The mbhaqanga and bubblegum genres owe their success to the South African Broadcasting Corporation; for they sounded largely apolitical. It was only towards the end of the twentieth century (during the 1980s) that jazz was found in the classroom, but, even then, only in a few white tertiary institutions such as Kwazulu Natal and Cape Town. ${ }^{103}$

\footnotetext{
${ }^{100}$ Chats Devroop. ““... Chasing the Canon...”: Opinion Piece', SAMUS: South African Music Studies 33/1 (2013).

${ }^{101}$ Makube, 'Our Kind of Jazz Post-1994'.

${ }^{102}$ Madimabe G. Mapaya, 'The Anatomy of the South African Jazz Appreciation Societies', Journal for Social Sciences 39/1 (2014), 60.

${ }^{103}$ See Devroop, ““... Chasing the Canon...”.
} 
According to Sam Mathe, the two decades before the advent of the democratic South Africa saw a significant jazz revival. ${ }^{104}$ This was a symptom of political development in the country. The new era ushered in a new social function for South African jazz, which became less a voice of resistance and more a matter of identity. Popular names included Moses Molelekwa, Moses Khumalo, Feya Faku, Andile Yenana, Prince Lengosa, and Zim Nqgawana.

New generations have continued to emerge, promoted by corporate and music industries and radio stations in the country such as Metro FM and Classic FM, and by events such as the Cape Town Jazz Festival, the Grahamstown Arts Festival, the Standard Bank Joy of Jazz, and others, which also bring in jazz musicians from all over the world. Such festivals, together with the jazz clubs that have been formed by classical jazz lovers, have helped to promote the art form in South Africa. ${ }^{105}$

During the twenty-first century, the new democratic South Africa has seen a changing political atmosphere and the opening of geographical space. The previous legacy of jazz that belonged to the night clubs and men only (invariably older men) has been replaced by a generation of young male and female musicians, and the discrimination in terms of gender, race, colour, and creed is no more. Since 1994, South African jazz and popular music have shifted from their political entrapments. From kwaito music, born out of modern township experience, which largely romanticized survival at all cost, the baton for social expression was taken over by

\footnotetext{
${ }^{104}$ Sam Mathe, 'The Voice of South African Jazz', Jazz Life: South Africa's Definitive Jazz Guide 1/1 (2013).

${ }^{105}$ Mapaya, 'The Anatomy of the South African Jazz Appreciation Societies', 60.
} 
house music, whose exponents have better general education and better handling of technological advancements.

These case studies illustrate how music in twentieth- and twenty-first-century South Africa has evolved in relationship to its colonialist past and the new identities of a postcolonial present. The examples discussed point to a different consciousness of history from that of the colonizing West; South Africa's expressive practices have taken a different form or played a different role, and need to be differently understood. The phases of a struggle over the terms of nationhood, rather than a division into centuries, are probably what determine any division into historical periods. From the mid-twentieth century onwards, choral music saw a stronger agenda to Africanize choral works emerging out of a black South African national consciousness. Jazz at this time was marginalized under the apartheid regime, and became a voice of the oppressed. In the post-apartheid era, a new generation of choral composers continue to integrate their Africanness into their creative oeuvre, even if they have not yet managed to totally shed Eurocentric traits. Jazz is now vehemently promoted such that it brings in musicians from all over the world. And whereas indigenous African music used to be mainly associated with ceremonies, rituals, socialization, and entertainment, new, democratizing trends have opened these practices up to widely diverse social groups, manifesting new identities, and fostering new forms of syncretism. All these more recent tendencies might be heard as the sounds and practices of 'the twenty-first century', but they can be equally and perhaps better understood as the fruits of the post-apartheid era. 


\section{$<$ A $>$ Post-war Music and Sound}

\section{$<$ AU >Benjamin Piekut}

$<$ Txt $>$ For scholars and students of the avant-garde, dividing modern music history at the century fails to create a periodization that satisfies nearly as well as 'post-war music and sound' does. ${ }^{106}$ The decades after 1945 hosted an unprecedented dehiscence and dispersal of advanced sonic practices: field recording, noise, open improvisation, installation, graphic notation, text scores, dub remixing, live signal processing, drone, turntablism, electro-acoustic improvisation, sound art, minimalisms, orchestral pop, sampling, new instruments, live coding, glitch, tape collage, new primitivisms, and biomusics. Arrayed across several genre formations, this vernacular avant-garde largely bloomed outside of the major recording/publishing companies and the university/conservatory system, employing a range of discourses but irreducible to any single hypostatized conception of radicalism. Although they generally resist the profit motive of the entertainment industry and the socio-aesthetic conservatism of academic and state-funded institutions, these diverse and often incompatible musics hardly escape the market or the academy completely. Musicology's general reluctance to engage with this advanced vernacular has created a peculiar situation. A discipline historically devoted to explaining and celebrating esoteric products of high culture has fallen mute in the face of a widespread diffusion of progressive avant-gardism into formerly low- and middlebrow positions.

\footnotetext{
${ }^{106}$ Thank you to Alejandro Madrid and James Currie for their thoughtful comments on earlier drafts of this text.
} 
Critically important to this transformation was the cohesion of a popular music aesthetics and an intellectual vernacular, first with bebop in the early 1940s and then, more quickly, with rock in the second half of the 1960s. ${ }^{107}$ These discourses established new kinds of connoisseurship and novel systems of evaluation for musics entwined in the commercial marketplace. By the 1980s, informal economies of exchange and curation - cassette tapes, zines, DIY punk production - would extend these extra-institutional listening practices to global repertoires. ${ }^{108}$ The emergent framework of judgement, distinct from numerical popularity and elite educational sites, did much more than invert the relationship or blur the line between high and low culture. Instead, it provided the grounds for the fracture of those two positions into new, intricate orders and relations, and the animation of fresh dialectical tensions among them.

These feral advanced musics fed on LP records and reproduced by the same means. They extended the lateral and processual movements of what Georgina Born calls 'the jazz assemblage', one of the many ways in which the social histories of afro-diasporic folk and popular musics have suffused global sonic production in the

${ }^{107}$ See Bernard Gendron, Between Montmartre and the Mudd Club (Chicago: University of Chicago Press, 2003); Phil Ford, Dig: Sound \& Music in Hip Culture (Oxford: Oxford University Press, 2013).

${ }^{108}$ See David Novak, 'The Sublime Frequencies of New Old Media', Public Culture 23/3 (2011). 
post-war period. ${ }^{109}$ Moreover, the vinyl LP recording tends to encourage promiscuous listening practices in its very standardization - one LP after another sequences Mary Lou Williams, gamelan, and the Pretty Things into the same musical flow - and the very abjection of popular music in its early history has helped it to absorb materials and techniques from other traditions; its devalued status meant less genre policing from critics in the know.

Phonography long predates Second World War, of course, but the long-playing vinyl record was cheaper to ship than an album of three or four shellac 78s, and the rapid post-war expansion of the North Atlantic recording industry meant that musics from around the world began to circulate and cross-pollinate with unprecedented speed. Accordingly, any account of advanced music-making after the Second World War has to leave what Richard Taruskin calls the 'literate tradition' ${ }^{110}$ With recordings, such cross-pollination could be effected through the ear alone, upending established structures of training and accreditation - vernacular innovators did not

${ }^{109}$ Georgina Born, ‘On Musical Mediation: Ontology, Technology and Creativity', Twentieth-Century Music 2/1 (2005).

110 Taruskin, The Oxford History of Western Music; see also Chris Cutler, File Under Popular: Theoretical and Critical Writings on Music (London: November Books, 1985). 
learn through composition lessons, university seminars, the exchange of scores, or attendance at new music festivals. ${ }^{111}$

The emergence of a new geopolitical and economic order also subtended new musical activities after 1945. The United Nations, the World Bank, the International Monetary Fund, non-state aid and philanthropic organizations, dual US/Soviet hegemony, regional bodies such as the League of Arab States, Third World decolonization, the non-aligned movement: these nascent institutions and movements affected more than just official events such as the First World Festival of Negro Arts in Dakar (1966) or the Warsaw Autumn Festival. They also produced the 'world heritage' discourse that would take Ali Akbar Khan LPs to Tony Conrad, or the trade agreements that would bring blues and jazz records to Tsegué-Maryam Guèbrou. And they channelled routes of international travel that took Takehisa Kosugi to Agra, Don Cherry to Mexico City, Miriam Makeba to Guinea, and Guy Warren (back) to Accra.

For those of us who teach something that used to be called 'twentieth-century music', it will become increasingly apparent that the post-war decades toss out new, unavoidable problems for the analysis of 'art music': the ruptures of Cage, noise, phonography, sound art, pop culture, improvisation, intermedia, globalization, electronics, and digitality, to name a few. Many of these were there before, of course, but not in a way that utterly scrambles existing historical narratives, as is the case after 1945. Therefore, I sense that the 'Music since 1900' survey will soon become a

\footnotetext{
${ }^{111}$ Chris Cutler, 'Probes 21', $R W M$, podcast, http://rwm.macba.cat/en/probes_tag (accessed 20 January 2017).
} 
thing of the past, as our colleagues re-segment the Western art-music history sequence to break at the Second World War.

Among the most salient of these unavoidable problems will be the changing nature of individual works and the tendency towards distributed authorship among artists informed by improvisational and vernacular musical practices. At the same time, work has grown increasingly linked to the body of its creator, who, bypassing the waystation of the definitive score, focuses more directly on the physical means of sound production and its preservation in recordings. One might formulate this change as the passage from a repertory-work model to a database model: musicians build up an ever-expanding individual database of instrumental and vocal techniques, technical setups, stylistic and aesthetic tendencies, stand-alone compositions, and highly personal approaches to improvisation, some or all of which might be drawn upon and recombined in a given performance. Concerts are less often occasions to present experimental 'works' than they are reports from an ongoing investigation. For instance, surveying the strong contributions of Cathy Berberian to Maderna's Dimensioni II, Berio’s Thema (Omaggio a Joyce), Cage's Aria, Pousseur's Phonemes pour Cathy, and Berio's Visage, we might surmise, with apologies to Manny Ramirez, that these compositions are just Cathy being Cathy. ${ }^{112}$

Taking shape between a popular music studies long concerned with musical consumption and a historical musicology devoted to the great works, these innovative post-war musics have fallen between the cracks of scholarly discourse. Our

\footnotetext{
${ }^{112}$ Mike Hume, 'A Brief History of the Phrase Manny Being Manny’, espn.com, 26 March 2009, www.espn.com/espnmag/story?id=3644816.
} 
colleagues in music curation have put us to shame in their support and understanding of this field, which has flourished under the direction of concert presenters such as Blank Forms (NYC), Issue Project Room (NYC), Tectonics (various sites), Roulette (NYC), Cafe Oto (London), the London Contemporary Music Festival, Other Minds (San Francisco), la Sala Rosa (Montreal), and the wulf (Los Angeles), as well as record labels such as die Schachtel, Unseen Worlds, Touch, Sublime Frequencies, Sub Rosa, and Important Records, many of which are performing the archival projects that musicology would usually contribute to. And there is a rich lineage of critical discourse too in journals such as Bells, Microphone, Musics, Impetus, Atem, Collusion, Ear, The Improvisor, ReR Quarterly, The Wire, Resonance, Rubberneck, Signal to Noise, Opprobrium, Improvised Music from Japan, Audion, and the Bull Tongue Review.

The documentation and discussion in these journals responds obliquely to the 'warning to black people in all disciplines of life' that Wadada Leo Smith issued in 1973: 'it is now time for us to take unto ourselves the process of recording our own history - to take this process from the control of those who are alien by the very being of their identity group to what it is that we are doing'. ${ }^{113}$ Smith's warning applies to all advanced vernacular musics, not just black ones. Students of these sonic practices owe a debt to those who have recorded this history thus far, but identity cannot be as inalienable as Smith assumes; if high-art-minded musicologists follow only the tracks of Schoenberg and Stravinsky into the second half of last century, we will continue to

\footnotetext{
${ }^{113}$ Leo Smith, Notes (8 pieces) Source a New World Music: Creative Music (Chicago: Corbett vs. Dempsey [1973] 2015), n.p.
} 
overlook the main headlines concerning advanced music of the last seventy years, to which I now refer as 'post-war music and sound'. The date I am finishing this essay 20 January 2017 - has me wondering how soon we will be referring to this same grouping as 'prewar music and sound', but I will leave that matter to a future writer.

\section{$<A>$ 'The Situation of a Creole'}

\section{$<$ AU $>$ George E. Lewis}

$<$ Txt $>$ One interpretation of this forum's questions implies an excursion in the direction of periodization. In music as elsewhere, the lengths of the twentieth and previous centuries (short, long) have been hotly debated, along with their endpoints, which are said to be expressed by rupture with the past. However, such ruptures appear to be local to culture and discipline; universalization has long seemed untenable in many fields.

Sir Donald Francis Tovey's 1949 essay 'The Main Stream of Music' posited an end to (Western classical) musical history, as well as foreshadowing Leonard Meyer's notion of 'fluctuating stasis', ${ }^{114}$ an absence of stable canon that Tovey evidently hoped would be a temporary condition:

$<$ Ext $>$ Having thus sketchily traced the main stream of music to what we may regard as the ocean of Wagner, I can go no farther. At the

\footnotetext{
${ }^{114}$ Leonard B. Meyer, Music, the Arts, and Ideas: Patterns and Predictions in Twentieth-Century Culture, 2nd edn (Chicago: University of Chicago Press, 1994).
} 
present day all musicians feel more or less at sea, and not all of us are good sailors. Some day the ocean-bed may rise again, and the Thames and the Rhine and other rivers may be seen to reunite as they did in the days when bisons were painted by realistic artists in the caves of Altamira. ${ }^{115}$

$<$ Txt $>$ I have read that twenty-first century music is in an analogous condition, and right on time to boot, at the onset of the new century, where Alvin Curran's buoyant prediction in 1994 of a 'New Common Practice' in which we will be 'freed of all rules, stylistic conventions, codes, and even ethics', appeared to Benjamin Piekut in 2004 to amount to no common practice whatsoever. ${ }^{116}$

Now that we have been in the new century for a while, I think we can see that Tovey's warning of an interregnum is actually rather welcome to many today. But will the metaphor of limbo suffice, or is there some more purposive trope or feature that already marks the twenty-first century?

Way back in 1984, Fredric Jameson ventured to 'periodize the 60s'

\footnotetext{
${ }^{115}$ Donald Francis Tovey, The Main Stream of Music and Other Essays (Cleveland and New York: Meridian Books, 1949), 351.

${ }^{116}$ Alvin Curran, 'The New Common Practice: Reflections of an American Composer in the Late Twentieth Century (Excerpt)', 15 March 1994, www.alvincurran.com/writings/common.html; Benjamin Piekut, 'No Common Practice: The New Common Practice and its Historical Antecedents', 1 February 2004, www.newmusicbox.org/articles/No-Common-Practice-The-New-Common-Practiceand-its-Historical-Antecedents/.
} 
even as he found such periodization 'theoretically unfashionable':

$<$ Ext $>$ the 'period' in question is understood not as some omnipresent and uniform shared style or way of thinking and acting, but rather as the sharing of a common objective situation, to which a whole range of varied responses and creative innovations is then possible, but always within that situation's structural limits. ${ }^{117}$

$<$ Txt> Jameson's annunciator for the 1960s begins 'in the third world with the great movement of decolonization in British and French Africa':

$<$ Ext $>$ all these 'natives' became human beings, and this internally as well as externally: those inner colonized of the first world 'minorities', marginals, and women - fully as much as its external subjects and official 'natives'. 118

$<$ Txt $>$ I do not think I have come across a general twentieth-century music history that periodizes by reconfiguration of the subjects of that history. If we follow along, we will need to ask, 'What are the modes of address for a subject of this discourse?'

One marker of the twentieth century's approach to Jameson's new subjects involved the anxious negativization of their subjectivity. This was exemplified by the queer African American pianist, singer, and composer

\footnotetext{
${ }^{117}$ Jameson, 'Periodizing the 60s', 178.

118 Jameson, 'Periodizing the 60s', 180-1.
} 
Julius Eastman's insistence on placing his own negativized subjectivity on the agenda of the downtown New York avant-garde, not least via difficult-todigest work titles such as Crazy Nigger and Nigger Faggot. ${ }^{119}$ In the end, colonization turns back to attack the colonizer: an auto-immune response. For many younger artists and audiences, as the consistent absences of the same ethnic, racial, and gendered voices from music histories and professional networks began to be increasingly noticeable, a form of anxiety began to set in, for which the negativized new subjects were often blamed.

As both new subjects and the traditional subjects that populate Western music histories become transformed into members of a new, positive collectivity, the new music and art that emerge become quasi-subjects along the lines imagined by Mikel Dufrenne's Phenomenology of Aesthetic Experience. ${ }^{120}$ Moreover, just as Jameson refers to 'the colonized, race, marginality, gender and the like' as 'subjects of history', ${ }^{121}$ our social and cultural histories and memories also become quasi-subjects, invested with (as Stanley Cavell puts it) 'a value which normal people otherwise reserve only

\footnotetext{
${ }^{119}$ See George E. Lewis, 'Foreword', in Gay Guerrilla: Julius Eastman and His Music, ed. Renée Levine Packer and Mary Jane Leach (Rochester: University of Rochester Press, 2016).

${ }^{120}$ Mikel Dufrenne, , The Phenomenology of Aesthetic Experience, trans. Edward S. Casey (Evanston, IL: Northwestern University Press, 1989).

${ }^{121}$ Jameson, 'Periodizing the 60s', 181.
} 
for other people'. ${ }^{122}$

According to David W. Bernstein, John Cage's fondness for James Joyce’s phrase ‘Here Comes Everybody' from Finnegan's Wake 'epitomized Cage's own pluralistic vision of politics, society, and art ... celebrating the uniqueness of individuals and the multiplicity of cultural differences around the world' ${ }^{123}$ A precursor to the current discussion that appeared in the second issue of this journal identified an analogous sentiment about the celebration of difference, with a model of 'liberal pluralism' that featured 'maximum feasible accommodation of diverse legitimate ways of life' and 'the practice of tolerance'. ${ }^{124}$ Similarly, in the early 1990s, musicologist Robert Morgan proposed 'a set of multiple canons that, taken individually, are relatively precise in delineation ... Under such circumstances a pluralistic musical culture could flourish, offering adequate provisions for different and divergent lines of development; yet a place would be preserved for valuative criteria'. ${ }^{125}$

${ }^{122}$ Stanley Cavell, 'Music Discomposed', in Must We Mean What We Say? A Book of Essays (Cambridge: Cambridge University Press, 1969), 198.

${ }^{123}$ David W. Bernstein and Christopher Hatch, ed. Writings through John Cage's Music, Poetry, and Art (Chicago: University of Chicago Press, 2001), 1.

${ }^{124}$ Clarke, 'Editorial: Twentieth-Century Music - Plural', 157.

${ }^{125}$ Robert P. Morgan, 'Rethinking Musical Culture: Canonic Reformulations in a Post-Tonal Age', in Disciplining Music: Musicology and its Canons, ed. Katherine Bergeron and Philip V. Bohlman (Chicago and London: University of Chicago Press, 1992), 61. 
Perhaps we should not be too sanguine about pluralism as a mode of address, however. Recalling art critic Hal Foster's pointed declaration that under pluralist social regimes, 'minor deviation is allowed to resist radical change', ${ }^{126}$ I can imagine a world beyond pluralism's uneasy, not-so-peaceful co-existence as a regulator of interchange among a host of supposedly incompatible canons. For example, Ania Loomba sees the possibility for what Edward Said called a 'contrapuntal method', where 'Western texts can be brought into conversation with a larger world by placing them within the geopolitics of their own time and ours'. ${ }^{127}$

Loomba continues, 'If we trace all that was borrowed and exchanged, we would have to include ideologies of color and of slavery, both of which were shaped by long histories of contact. ${ }^{128}$ Such memories tend to destabilize pluralisms that concentrate on preserving difference while failing to analyse power, reconfigure the subject at its root, or provide safeguards against the ugly recrudescence of what bell hooks consistently calls 'white supremacist capitalist patriarchy'. ${ }^{129}$

Alternatively, I want to venture that twenty-first century music is

\footnotetext{
${ }^{126}$ Hal Foster, Recodings: Art, Spectacle, Cultural Politics (Seattle: Bay Press, 1985), 13.

${ }^{127}$ Ania Loomba, 'Periodization, Race, and Global Contact', Journal of Medieval and Early Modern Studies 37/3 (2007), 601 .

${ }^{128}$ Loomba, 'Periodization, Race, and Global Contact', 603.

${ }^{129}$ bell hooks, Black Looks: Race and Representation (New York: Routledge, 2014), 84.
} 
becoming marked by a condition of créolité. Éloge De La Créolité, an influential 1989 manifesto crafted by Caribbean writers Jean Bernabé, Patrick Chamoiseau, and Raphael Confiant begins with this ringing declaration:

$<$ Ext $>$ Neither Europeans, nor Africans, nor Asians, we proclaim ourselves Creoles. This will be for us an interior attitude - better, a vigilance, or even better, a sort of mental envelope in the middle of which our world will be built in full consciousness of the outer world. ${ }^{130}$

$<\mathrm{Txt}>$ According to these writers, 'Creoleness is an annihilation of false universality, of monolingualism, and of purity'. ${ }^{131}$ Nor is créolité limited by language: 'Its appetite: all the languages of the world.'132 'The world is evolving into a state of Creoleness', they write;

$<$ Ext $>$ The old national immovable organizations are being replaced by federations which in turn might not survive for long ... The son or daughter of a German and a Haitian, born and living in Peking, will be torn between several languages, several histories, caught in the torrential ambiguity of a mosaic identity. To present creative depth, one must perceive that identity in all its complexity. He or she will be

\footnotetext{
${ }^{130}$ Jean Bernabé, Patrick Chamoiseau, and Raphael Confiant, Éloge De La Créolité, trans. M. B. Taleb-Khyar (édition bilingue français/anglais) (Paris: Gallimard, 1993), 75.

${ }^{131}$ Bernabé et al., Éloge De La Créolité, 90.

132 Bernabé et al., Éloge De La Créolité, 108.
} 
in the situation of a Creole. ${ }^{133}$

$<$ Txt $>$ This situation, which we can see as a version of Jameson's 'common objective situation', is what I invite people to hear in twenty-firstcentury music. Like Caribbean Creoleness, the new sonic créolité is fuelled by a trope of improvisation-as-mobility, whether forced, as with resistance to chattel slavery; voluntary, as with the Great Migration, the largest and longest internal migration in US history, an Occupy-the-North-style improvisation of distributed intelligence pursued over half a century by ordinary working-class African Americans; or virtual, in the form of the World Wide Web, the largest collective improvisation ever created. The mobile musical subject becomes reconfigured in ways that pluralism cannot hear, resulting in new musical forms that exceed the limitations of postmodern pastiche.

We have already seen the Mississippi join the Rhine and the Thames in the twentieth-century musical imagination. It seems evident that this new confluence of streams is rising as the new century unfolds, and perhaps, as Bernabé, Chamoiseau, and Confiant have proclaimed, 'Our aesthetics cannot exist (cannot be authentic) without Creoleness. ${ }^{, 134}$ As Gayatri Chakravorty Spivak has observed, '[C]reolity ... is about the delexicalization of the foreign ... It will yield us a history and a world.' ${ }^{135}$

\footnotetext{
${ }^{133}$ Bernabé et al., Éloge De La Créolité, 112.

${ }^{134}$ Bernabé et al., Éloge De La Créolité, 89.

${ }^{135}$ Gayatri Chakravorty Spivak, 'Dialogue: World Systems \& the Creole', Narrative 14/6 (2006), 106.
} 


\section{$<A>$ Productive Confusions: The Shifting Field of Free Improvisation in the}

\section{Twenty-first Century}

\section{$<$ AU >David Toop}

$<$ Txt $>$ One of the defining events of the twentieth century, the so-called Great War was over by 1918. Millions of deaths, mechanized warfare, gas attacks, bombing from the air all presaged the future. Many of the old institutions and structures were damaged, if not entirely eliminated.

The twenty-first century has reached a similar point, in years and instability if not in the specifics. Is it possible to look back and discern a substantial difference between cultural practices then and now, in particular in the field of music? Reactions to the First World War ranged from glorification (from at least some of the Italian Futurists, whose thirst for an entirely new world was embodied by the dynamic force of exploding shells) to the dissenting absurdity of Dada. The 'isms' of modernism that began in the late nineteenth century now began to line up in the history books as if neatly contesting and replacing each other.

Within music there were areas of less clarity, free improvisation among them. For many years this was legitimized or dismissed as a hybrid of two mid-twentiethcentury modernisms - free jazz and chance music - as if their antipathetic principles hot and cool, random and intuitive, politically committed or detached - could be grafted into an unprecedented fusion of both. Yet the evolution of free improvisation, a musical strategy eschewing composer, score, or conductor, even free jazz head arrangements, Fluxus text instructions or the I Ching of indeterminacy, turns out to be 
far more complicated. The culture of spontaneity was an intricate web of connections linking impressionist painting, Dada exhibitionism, surrealist automatism, stream-ofconsciousness writing, jazz and certain strains of rock and funk, abstract expressionism, performance happenings, improvised theatre, sound poetry, and other manifestations of action art. If this can be described as a tradition, then free improvisation was a part of it. A hybrid, then, but not a simple one.

Given its complications (not to mention its marginality), free improvisation has been less prone to its own successions of 'isms'. There have been convulsions, such as the emergence of reductionism in the 1990s, but gradually these have been absorbed or modified to enrich the available vocabulary. Hindsight also tells us that such tendencies have always been present in the music, often running in parallel with their opposite. With this sense of continuity across tactics and generations, is it possible to delineate any clear distinction between twentieth- and twenty-first-century free improvisation?

The most obvious example of difference is technological. The use of laptop computers as live improvising instruments became possible in the late 1990s, as laptops became faster and more stable. Fenn O'Berg, the trio of Christian Fennesz, Jim O'Rourke, and Peter Rehberg, released their first record of laptop improvisations in 1999, edited together from a world tour spanning 1998-99. Their debut performance was an appearance at the Nickelsdorf Festival in Austria, an event closely associated with free jazz ancestry and the acoustic proclivities of free improvisation. With the new millennium their example was followed by many younger players, a turn that provoked endless controversy. Could a laptop be considered as an instrument? Was it not boring to watch, detached from human agency, remote from the body, unresponsive and slow, an expression of power by 
both/either the operator and/or the corporation that produced the hardware and its software applications? Although such questions were valid as a millennial anxiety 'the machines are taking over' (not many years later this seems an increasingly likely possibility) - they were primarily articulations of aesthetic positions, usually connected to the formative years of free improvisation when the music advocated a 'natural' approach to the instrument, to sound, and to the collaborative character of group listening.

Laptops are now a relatively common sight among the improviser's kit, though they are likely to be adding processing potential to demonstrably physical activities, such as playing a conventional or homemade instrument, modular synthesis, voice, or the myriad ubiquitous small devices often described as objects. For all its notoriety as an instrument to divide generations or philosophies, the laptop's rise as a symbol of hypermodernity was brief. As in many other fields of twenty-first-century music production and reproduction, free improvisation embraced the antithetical tendency of retro, returning to analogue and cracked electronics, turntables, modular synthesis, amplified surfaces, and objects.

Indivisibly linked to the rise of laptops and a shift to digital mobility came a phenomenon that affected all music, the apparent collapse of recorded music as a viable adjunct to performance. Free improvisers are rarely given credit for being pioneers of independent labels yet in the early 1970s labels such as Incus, ICP, and FMP anticipated by some years the more celebrated explosion of punk labels. Releasing records has always been somewhat anomalous for a music so tied to space, place, time, and the presence of its making, yet without records improvisers would struggle to build reputations, careers, or continuity, let alone a collective memory of the music. For a short time the advent of email, the internet, early social media sites 
such as Myspace, and home production using CD-Rs seemed to have converged to create an improviser's paradise: finally, an opportunity to self-produce with virtually no costs and no constraint. Small labels proliferated but the sheer weight of material that became evident as globalization took effect became self-defeating. Filesharing obliterated the twentieth-century idea that buying records was one of the central tenets of being a music lover. For a time, recordings in all formats were tainted either with the smell of the twentieth century or the insubstantiality of the twenty-first.

In retrospect, many of the changes affecting improvisation were as healthy as they were inevitable, encouraging bouts of soul searching that further dislodged ties to those 1960s ideals out of which free improvisation had sprung. As with most other genres fifty years ago, free improvisation was predominantly a male activity. Consequently its milieu and general tone could display some of the worst traits of masculinity. In the twenty-first century the gender balance is becoming far more even. It is also possible to find pockets of free improvisation almost anywhere in the world, some of them entirely unaware of the music's history. The focus of these scenes tends to be local and global, creating a music that is tied closely to local conditions yet alert to the speed and ease with which information is disseminated and devoured through online platforms such as YouTube.

One of the most striking effects of this trend has been the appropriation of free improvisation's core philosophy - a music without composer, score, or other preparatory material - by other genres of music and sound work. Noise music is one example, distinguished by its narrowed focus on extreme, so-called harsh electronic noise but at base a form of free improvisation. These tendencies come together with the Jogja Noise Bombing community of Yogyakarta, a loose grouping that sets up their homemade amplified instruments and effects pedals and improvises until driven 
away by security. They describe themselves as concentrating on experimental audio, noise, harsh noise, ambient, drone, circuit bending, etc., and in that list of cohabiting genres articulate one of the most significant shifts away from twentieth-century tribalism.

The rise of sound art, also traceable in its current manifestation to the end of one century, and the dawn of another, has contributed to a blurring of lines between all the elements that constitute music: its possible settings, durations, forms, presences, and materials. Despite its contentious implications, R. Murray Schafer's 1960s term soundscape - is now routinely applied by non-experts to site-specific sound installations, free improvisations, ambient music, field recordings, electro-acoustic and drone compositions, noise, experimental radio montages, and any artwork that uses sound in some way.

While threatening to homogenize activities that may be at opposite ends of the spectrum, this view of music as a field of relatable workings with sound and listening has been internalized as a basic condition of much twenty-first-century music. Of course it is built on the work of twentieth-century musicians, composers, artists, theorists and their 'isms', yet in its productive confusion it has a character and vitality all of its own.

\section{$<$ A $>$ Music as Data in the Twenty-First Century}

\section{<AU>Noriko Manabe}

$<$ Txt $>$ Since around the beginning of the twenty-first century, the internet has had a greater transformative impact on musical production and consumption than any other 
factor. Internet streaming is now the most prevalent way of consuming music, making up 59 per cent of digital revenues (which themselves comprise 50 per cent of all recorded revenues). More than 100 million people rent music through paid subscriptions, and record collecting increasingly seems the quaint hobby of ageing baby boomers and purist DJs. ${ }^{136}$ How is consumption of music over the internet a continuation of social and technological trends of the twentieth century, and how is it not?

As Sumanth Gopinath and Jason Stanyek have pointed out, the marketing mantra of music 'anytime, anywhere' has been around since the days of the Edison phonograph. ${ }^{137}$ With improved radio reception and the miniaturization of components, progressively smaller and more mobile machines - car radios, transistor radios, the Walkman, iPods, smartphones - made it increasingly possible to have music around us at all times, and for us to choose the music of our own liking. The dominance of the smartphone in our listening habits today can be seen as a continuation of these larger trends. For the online radio service Pandora, streaming through mobile phones accounted for 86 per cent of its total listener hours in $2016 .{ }^{138}$

\footnotetext{
${ }^{136}$ IFPI, 'Global Music Report 2017: Annual State of the Industry', IFPI Report, 25 April 2017, www.ifpi.org/downloads/GMR2017.pdf.

${ }^{137}$ Sumanth Gopinath and Jason Stanyek, 'Anytime, Anywhere? An Introduction to the Devices, Markets, and Theories of Mobile Music', in The Oxford Handbook of Mobile Music Studies, vol. 1, ed. Sumanth Gopinath and Jason Stanyek (New York: Oxford University Press, 2014), 16.

${ }^{138}$ Pandora Media, 'Pandora 10-K, December 2016', 10-K Annual Report to the U.S. Securities and Exchange Commission, 15 February 2017, http://investor.pandora.com/Doc/Index?did=39496989.
} 
The business model by which we consume recordings has also been changing. In the twentieth century, a listener could possess music in tangible form (e.g., sheet music, piano roll, record, cassette, CD), or hear a broadcast on radio or television, often for free. The record and radio industries had generally coexisted in mutually beneficial relationships, in which radio received product to fill air space while it promoted records to the public; listeners bought records, and radio financed itself through advertising. In the early twenty-first century, the most prevalent options became digital files to own and Pandora-style online radio for free listening; since around 2006, on-demand streaming through Spotify-style services and YouTube, both potentially free, have supplanted file ownership. Listeners no longer have to buy music to own; they can 'rent' it through subscription services or hear it for free. With that in mind, the beginning of the twenty-first century could be said to be marked by the birth of Napster in 1999, as the peer-to-peer service made the digitized, in-thecloud model of music inevitable.

Napster created an ethos that music should be free and accessible on the internet, ${ }^{139}$ and shutting it down only led to new, more distributed modes of sharing. The prevalence of piracy made it extremely difficult for earlier subscription services like Rhapsody to gain traction. Hence, it was Pandora's free streaming service that first achieved widespread diffusion; as of 2016, it boasted 100 million listeners a quarter, a 55 per cent share of streaming hours in the US, and a billion dollars in

\footnotetext{
${ }^{139}$ Matthew David, 'The Legacy of Napster', in Networked Music Cultures: Contemporary Approaches, Emerging Issues, ed. Raphael Nowak and Andrew Whelan (London: Palgrave Macmillan, 2016).
} 
annual advertising revenue. Yet despite this industry dominance, it saw widening operating loss margins on its main content business between 2014 and $2016 .{ }^{140}$ The picture at Spotify, whose revenues come primarily from subscriptions, is equally precarious. Despite having nearly doubled its paying subscribers to 50 million, as of March 2017, and increased its revenues by nearly 50 per cent year-on-year to $€ 2.9$ billion in 2016, operating losses for that year appear to have roughly doubled. ${ }^{141}$ Unlike previous periods, where distributors such as Walmart and iTunes became powerful, neither advertising-centric Pandora nor subscription-centric Spotify is generating cash, despite having achieved massive scale and dominant positions. The high cost of royalties has pressured margins for both companies, but with music industry revenues at half of their peak of the late 1990s, rights holders are unlikely to accept large reductions in royalty rates soon.

As it looks increasingly unlikely that streaming music alone will generate profits, these services are being forced to find monetization elsewhere, and are looking instead to data mining of user behaviour. As Tim Anderson has argued, 'deep data profiles that are ready to be mined in one experiment after another to secure higher probabilities of the sale $\ldots$ is where the value resides' ${ }^{142}$ Music is a

${ }^{140}$ Pandora, ' $10-\mathrm{K}$ '.

${ }^{141}$ Alfred Lee, 'Spotify’s Loss Widens Despite Big Jump in Revenue’, The Information, 18 May 2017, www.theinformation.com/spotifys-loss-widens-despite-big-jump-in-revenue.

${ }^{142}$ Tim J. Anderson, Popular Music in a Digital Music Economy: Problems and Practices for an Emerging Service Industry (New York: Routledge, 2014), 71. 
particularly useful data mine because it is so ubiquitous; ${ }^{143}$ it accompanies our every activity and exemplifies who we are. The smartphones through which we listen transmit a tremendous amount of data, including our locations and preferences. Spotify and Pandora are more valuable as research organizations that deliver targeted audiences than as music services. For other streaming services - Apple, Google, Amazon - streaming music itself need not generate profits; the music services enhance their data, which could be mined to benefit their other businesses.

While the radio station can only target metropolitan areas and broad ageethnicity demographics, streaming services can micro-pinpoint individuals by musical taste, even refined by the time of day, location, and activity in which they are engaged. In doing so, they make judgements as to the type of person a listener is. This capacity for data mining is the most profound difference between the past century and the present, with ramifications for not only music but also social and political life.

Streaming services are correlating listening data to psychographic characteristics - personality, attitudes, interests, lifestyles, etc. - that advertisers can then target. The Echo Nest, acquired by Spotify, developed five taste profiles of listeners: 1) diversity of music genres played;2) mainstreamness, the degree of preference for top hits; 3) freshness, the preference for new releases; 4) locality, the geographic spread of a listener's artists; and 5) adventurousness, listeners' openness

\footnotetext{
${ }^{143}$ See Anahid Kassabian, Ubiquitous Listening: Affect, Attention, and Distributed
} Subjectivity (Berkeley: University of California Press, 2013). 
to music outside their comfort zones. ${ }^{144}$ Listeners with more eclectic musical tastes are thought to have higher incomes and social status; they are targeted with advertisements for expensive items. ${ }^{145}$ Pandora infers Spanish speakers through musical selection. Both services presume political affiliation through musical taste: funk, hip-hop, salsa, indie, and electro lean Democratic; Christian and country lean Republican. ${ }^{146}$ This finely grained data could be used to identify the lone Democrats in a Republican zip code.

Spotify can learn that a listener runs every morning, and generate playlists to match her running pace at that time. It also knows how the weather affects musical choices in a given city and can offer mood-smoothing music on a rainy day. It is also integrated with Tinder, a dating app with its own algorithms to match users based on swiping patterns, mutual friends, and common interests. This tie-up allows users to broadcast a particular song on their Tinder profiles and display their most-heard artists and songs. It was hailed 'el mejor filtro ever' (best filter ever) by one user, and another tweeted that she 'would like to avoid a grown man who listens to twenty one

\footnotetext{
${ }^{144}$ Brian Whitman, 'How Music Recommendation Works - and Doesn't Work', Variogram, 11 December 2012, https://notes.variogr.am/2012/12/11/how-musicrecommendation-works-and-doesnt-work/.
}

${ }^{145}$ Robert Prey, 'Musica Analytica: The Datafication of Listening', in Networked Music Cultures: Contemporary Approaches, Emerging Issues, ed. Raphael Nowak and Andrew Whelan (London: Palgrave Macmillan, 2016), 39, 40.

146 See Glenn McDonald, 'Genre Politics', Furialog, 21 April 2017, www.furia.com/. 
pilots' - a data point to be correlated and crunched. Such examples of extreme contextualization may be useful to some listeners but also have invasive overtones.

Data mining carries a number of social issues beyond privacy. Algorithms may sound scientific and impartial, but they function according to the preconceptions and prejudices of their human designers. Tarleton Gillespie has outlined several dimensions by which algorithms have sociopolitical implications. ${ }^{147}$ Algorithms are only as good as their databases. What patterns or criteria determine which objects are included or excluded, or how they are categorized? Pandora's musicologists manually analyse each track in its catalogue - a time-consuming exercise that causes the inclusion of only those songs they believe 'users would like'. ${ }^{148}$ Amazon correlates purchases against other purchases, excluding tracks with less activity, leading to popularity bias. ${ }^{149}$ More seriously, algorithms may make flawed inferences about users. Information systems produce shadow bodies of users that emphasize some aspects but overlook others, so that there is slippage between the anticipated user and the actual user. What might be a temporary pattern could be interpreted as timeless, or the pattern of a few users could be taken as universal.

\footnotetext{
147 Tarleton Gillespie, ‘The Relevance of Algorithms', in Media Technologies: Essays on Communication, Materiality, and Society, ed. Tarleton Gillespie, Pablo J. Boczkowski, and Kirsten A. Foot (Cambridge, MA: MIT Press, 2014).

${ }^{148}$ Noriko Manabe, ‘A Tale of Two Countries: Online Radio in the United States and Japan', in The Oxford Handbook of Mobile Music Studies, vol. 1, ed. Sumanth Gopinath and Jason Stanyek (New York: Oxford University Press, 2014).

${ }^{149}$ Whitman, 'How Music Recommendation Works'.
} 
Consumers themselves can become complicit in these processes. Gillespie argues that 'users may shift their worldviews to accommodate the underlying logics and implicit presumptions of the algorithms they use regularly'. ${ }^{150}$ Because Facebook's algorithms more prominently display those updates that receive more Likes and comments, users may adopt participatory behaviours that improve their status placements. In turn, this activity produces a cyberspace public and shapes its sense of self.

Streaming services present themselves as a listener's utopia, tailoring music to each individual's tastes and situation. But as Eric Drott points out, music's very ubiquity and personalization makes it the 'ideal tracking device, providing unique insights into who we are, how we feel, what we do, and how these fluctuate from one moment to the next'. ${ }^{151}$ Such data is already used to sell us products and congressional candidates based on our presumed beliefs, ethnic affinities, wealth, and habits. It could also be harnessed to shape our opinions, targeted through musical taste and smoothed by the mood-affecting music of our choice. Just as in centuries gone by, music can be used for propagandistic purposes - only this time, it doubles as a data source, and it can be tailored specifically to each individual.

${ }^{150}$ Gillespie, ‘Algorithms’, 187.

${ }^{151}$ Eric Drott, 'Music as a Technology of Surveillance', paper presented at the American Musicological Society Annual Conference, Vancouver, 3-6 November 2016. 


\section{$<\mathrm{A}>$ Music after the Death of Art}

\section{$<$ AU $>$ Roger Redgate}

$<T x t>$ Whether it's meaningful to discuss art and music in terms of centuries remains doubtful. ${ }^{152}$ After all, we were told in the 1990s that the ways in which the past has been historicized - in the form of linear metanarratives - was something of a modernist conceit that had begun to look old-fashioned as we moved into a postmodern era - or should I say 'condition'? ${ }^{153}$ This already seems like a well-worn discussion that itself can now be safely historicized; nevertheless it marked a significant cultural turn towards the end of the twentieth century. Postmodernism's weakening of a sense of history led further to the possibility of an 'end of history'. Inevitably, however, with various subsequent political uprisings and now more recent political ruptures in particular, history seems to have been reborn. ${ }^{154}$ Perhaps

\footnotetext{
${ }^{152}$ Although this article is intended specifically to address music in the twenty-first century, the issues discussed relate to the wider context of art in general.
}

${ }^{153}$ See Keith Jenkins, Why History? Ethics and Postmodernity (London: Routledge, 2001); and JeanFrançois Lyotard, The Postmodern Condition: A Report on Knowledge, trans. Geoffrey Bennington and Brian Massumi (Minneapolis: University of Minnesota Press, 1984).

154 The time of writing seems to represent a particular point of political instability, ranging from the problems in the Middle East (the so-called Arab Spring), to the rise of political 'outsiders' such as Donald Trump in the US and Macron and Le Pen in the recent French elections. Russian/American relationships are at an all-time low since the Cold War; globalization is increasingly threatened with the rise of nationalism and in some cases the far right, and there is potential nuclear conflict between the US and North Korea. See also Alain Badiou, The Rebirth of History: Times of Riots and Uprisings, trans. Gregory Elliott (London: Verso Books, 2012). 
Adorno's view of art being defined by a historically changing constellation of moments remains appropriate after all. ${ }^{155}$

Of course this ending was not really an end of history per se, but rather a proposed endpoint of humankind's ideological evolution, and the supposed universalization of Western liberal democracy. A significant feature of this particular 'ending' was a neoliberalist celebration of capitalist values. As Fredric Jameson pointed out, there is 'some agreement that the older modernism functioned against its society in ways which are variously described as critical, negative, contestatory, subversive, oppositional and the like', whereas postmodernism 'replicates and reproduces - reinforces - the logic of consumer capitalism' ${ }^{156}$ Significantly, Jameson leaves open the question whether there is potentially also a resistant strain of postmodernism capable of contesting such a logic in a culture that thrives on conservatism, conformity, and marketability.

I do not really want to reawaken the old modernism/postmodernism debate, other than to observe the distinction between postmodernism and postmodernity argued by Terry Eagleton: the former 'a style of culture' and the latter a 'style of thought' - closely related perhaps, but one rather playful and the other much more pernicious. ${ }^{157}$ Along with rumours of the death of the subject, the time spent in the

\footnotetext{
155 Theodor W. Adorno, Aesthetic Theory. trans. Robert Hullot-Kentor (London: Continuum, 2004).

${ }^{156}$ Frederic Jameson, 'Postmodernism and Consumer Society', in The Cultural Turn: Selected Writings on the Postmodern 1983-1988 (London and New York: Verso, 1998).

157 Terry Eagleton, The Illusions of Postmodernism (Oxford: Blackwell, 1996).
} 
subsequent postmodern wilderness further seemed to suggest the death of art; Arthur C. Danto even speaks in terms of a 'post-historical art'. ${ }^{158}$

What effect did the fallout from these conditions have on art and music as we moved into the twenty-first century? Where does it leave us culturally, and what are the implications for the sociopolitical economy of art? Even a theoretical ending of art or history can have a long-lasting impact, leaving a residue that becomes accepted as a habit of thought. Contemporary music (whatever that means today) seems plagued with the need for theoretical parallels and justifications to affirm its cultural relevance, aligning itself to, or even being informed by such debates - however naive or ill informed. Even recent uses of language reflect a cultural change: the rise of now commonplace expressions such as the 'music industry' and 'creative industries' reinforces music's increasing status as a commodity, which extends more insidiously beyond a basic principle of marketability, profit, and capital accumulation, to aspects of arts funding and commissioning, the policies of arts organizations and institutions, the programming polices of orchestras and new music ensembles, and consequently the attitude of young composers and performers.

Indirectly, then, language has a subtle way of imposing ownership and containment, which itself often harbours its own kind of oppression. In the light of all this, the new millennium certainly articulated a structural change - a change that had its origins in the widest reaches of society and the economy, and that brought about a radical re-configuration of meaning.

\footnotetext{
${ }^{158}$ Arthur C. Danto, After the End of Art: Contemporary Art and the Pale of History (Princeton: Princeton University Press, 1997).
} 
Already in 1974 Peter Bürger warned of how art is increasingly made with profit in mind and how the culture industry has 'brought about the false elimination of the distance between art and life'. ${ }^{159}$ Bürger's comments relate to the relative autonomy of art in a bourgeois society that appropriates aesthetic production to its own ends. This has further resonance with Jacques Rancière's view, albeit from a different perspective, of 'the aesthetic regime of art': 'aesthetic because the identification of art no longer occurs via a division within ways of doing and making, but ... is based on distinguishing a sensible mode of being specific to artistic products' ${ }^{160}$ Rancière argues that 'modernism' is a problematic term that prevents us from dealing with the politics of radical forms of art, more properly termed 'aesthetic'. 161 'Aesthetic', he says 'designates the suspension of every determinate relation correlating the production of art forms and a specific social function. ${ }^{162}$ Music in the twenty-first century seems marked, if not defined, by this 'elimination of distance', which is a cultural turn informed by the corporate values of late capitalism, where market forces overrule artistic considerations. A 'death of art' would engender

${ }^{159}$ Peter Bürger, Theory of the Avant-Garde, trans. Michael Shaw (Minneapolis: University of Minnesota Press, 1984), 50

160 Jacques Ranciére, The Politics of Aesthetics: The Distribution of the Sensible, trans. Gabriel Rockhill (London and New York: Continuum International Publishing, 2004).

${ }^{161}$ Joseph J. Tanke, 'What is the Aesthetic Regime?' Parrhesia: A Journal of Critical Philosophy 12 (2011), http://parrhesiajournal.org/parrhesia12/parrhesia12_tanke.pdf.

162 Jacques Ranciére, 'The Paradoxes of Political Art', in Dissensus: On Politics and Aesthetics, ed. and trans. Steven Corcoran (London and New York: Continuum International Publishing Group, 2010). 
an art trivialised to the extent that it becomes incompetent to deal with the problems of being human. The British playwright Edward Bond has discussed this at length in terms of a cultural disaster, and remarked how the marketization of human values 'systematize life in a desperate striving for profit'. ${ }^{163}$

Ranciére's 'aesthetic regime' seeks to re-configure the common experience of the sensible in favour of re-asserting art's capacity to resist forms of economic, political, and ideological domination, with a view to forging a symbiotic relationship between politics and aesthetics: 'Critical art is an art that aims to produce a new perception of the world, and therefore to create a commitment to its transformation. ${ }^{164}$ Whether the twenty-first century actually marks the beginning of a new era in music remains to be seen. However, there can be no meaningful discussion of music today that does not engage with the forces of such a political economy. The German writer and filmmaker Peter Weiss proposed that meaning lies in the refusal to renounce resistance, no matter how intense the oppression, and that it is in art that new models of political action and social understanding are to be found. ${ }^{165}$ The nature of such a resistance would be similarly defined by a changing constellation of moments in the political sphere. In a recent musical context, the work of composers

${ }^{163}$ Edward Bond, 'Education, Imagination and the Child', in Letters 4, vol. 4, selected and ed. Ian Stuart (London: Harwood Academic, 1998), and The Hidden Plot: Notes on Theatre and the Stage (London: Methuen, 2000).

${ }^{164}$ Ranciére, Dissensus: On Politics and Aesthetics.

165 Peter Weiss, Die Ästhetik des Widerstands, 3 vols. (Frankfurt: Suhrkamp Verlag, 1975, 1978, 1981). 
such as Richard Barrett, Brian Ferneyhough, Helmut Lachenmann, and Luigi Nono would seem to fulfil this role. ${ }^{166}$ One can only hope that music of the twenty-first century will further embrace such resistance.

\section{$<$ A $>$ Neoliberal Musicologies}

\section{<AU >Marie Thompson}

$<$ Txt $>$ On the website of the Mannes School of Music (part of the New School, New York), prospective students can browse their options for declaring a minor. The website promises that 'every time you cross into a new discipline, you increase your relevance to a world that equates creativity with multidisciplinary talents'. ${ }^{167}$ A minor in the provocatively titled 'post-genre music: performance and creation' is said to prepare the twenty-first-century musician for 'a world where musicians can no longer stay confined to a single genre' and where 'performers need to be able to survive and thrive in a wide variety of styles of music and, increasingly, in music that combines many different styles into one'. ${ }^{168}$ In a 'post-racial, 'post-sexist', 'post-class', 'postidentity', 'pro-diversity', and 'pro-heterogeneity' society, genre becomes obsolete.

\footnotetext{
${ }^{166}$ For a related discussion, see Ross Feller, 'Resistant Strains of Postmodernism: The Music of Helmut Lachenmann and Brian Ferneyough', in Postmodern Music/Postmodern Thought, ed. Judy Lochhead and Joseph Auner (New York and London: Routledge 2002).

${ }^{167}$ Mannes, The New School, 'Minors', n.d., www.newschool.edu/mannes/minors/.

${ }^{168}$ Mannes, The New School, 'Post-genre music', n.d., www.newschool.edu/mannes/minors-postgenre-music/.
} 
The musical worker should know that flexibility, adaptability, and resilience are qualities that are more frequently rewarded rather than fidelity to a particular musical style.

It is strange to be writing about an ideological consensus that, in some parts of the world at least, appears to be crumbling. Nonetheless, neoliberalism - a pervasive, hyper-individualist and heterogeneous ideological schema that seeks the expansion of market principles to all aspects of social life - and music - as an art-form, as a mode of physical and affective labour, as social practice, as a technology of selfmanagement, and as commodity - have been thoroughly entangled over the course of the late twentieth and early twenty-first centuries. ${ }^{169}$ This relationship has garnered little attention from within musicology: as Javier León notes, despite emerging in the 1970s neoliberal economic reforms, their impact on social, cultural, and political life have seldom been treated as a central theoretical concern. Instead, neoliberalism has been 'something of a drone accompaniment to contemporary discussions about music and music making; a ubiquitous presence that provides a requisite context for other interrelated inquiries, but one that is also quickly forgotten or taken for granted' ${ }^{170}$ It is my contestation that, insofar as music and its socioeconomic context are co-

\footnotetext{
${ }^{169}$ For a concise overview of some of neoliberalism's definitions, see Jeremy Gilbert, 'What Kind of Thing is Neoliberalism?' New Formations 80/81 (2013).

${ }^{170}$ Javier León, 'Introduction: Music, Music-making and Neoliberalism', Culture, Theory and Critique 55/2 (2014), 129. Some notable works that have explicitly addressed the relationship between music and neoliberalism include Robin James, Resilience and Melancholy: Pop Music, Feminism, Neoliberalism (Winchester: Zero Books, 2015); Timothy D. Taylor, Music and Capitalism: A History of the Present (Chicago: University of Chicago Press, 2015).
} 
constitutive, a distinction between 'pre-' and 'post-' neoliberal music cultures is, in at least some geopolitical locations, a more pertinent historiographical distinction than one drawn between twentieth- and twenty-first-century musics.

The departure from genre can be considered one of the many cultural symptoms of the emergence of neoliberalism from liberalism. Classical liberalism pertains to a political philosophy that treats the individual as the primary political actor. However, who gets to be an individual under liberalism has always been partial and selective: in theory, liberalism espouses values of freedom, equality, and liberty; in practice, these values are extended to some and withheld from others, often on the basis of race and gender. Where liberalism included and excluded on the basis of identity (insofar as the political individual was conceptualized apropos of white, straight masculinity), neoliberalism is said to overcome these exclusions through a 'post-identity' politics. Robin James argues that pop culture's shift from clearly defined musical styles towards 'post-genre' musicality resonates with this broader social shift from the perceived 'purity' of identity and collectivity towards (selectively defined notions of diversity, heterogeneity, and individuality of neoliberalism: the post- of 'post-genre' is the post- of post-identity. ${ }^{171}$

The apparent decline of genre in some facets of musical culture has been accompanied by an amplification of functionality. Music's capacity to generate particular affective states appropriate to a specific context becomes a key organizational feature. Streaming services, for example, offer themed, multi-genre playlists that aim to induce a particular 'vibe': Spotify's 'Walk Like A Badass'

\footnotetext{
${ }^{171}$ Robin James, 'Is the Post- in Post-identity the Post- in Post-genre?' Popular Music 36/1 (2017).
} 
playlist is said to help the listener 'strut the streets like the badass you are'; while 'Feel good Friday' provides 'non-stop feel-good songs to power you through 'til the weekend'. The personalization of musical playback technologies means that the listener can use music as a technology of self-regulation and mood management with increasing ease. These technologies have helped listening modes and contexts become fluid and 'diverse': any type of music may, technically speaking, become 'ubiquitous' music (including those that are ordinarily associated with the concert hall and the academy), just as any type of music, technically speaking, may become a weapon of torture in the detention camps of contemporary wars. ${ }^{172}$

Music and its capacity to induce a particular 'vibe' has also been integral to neoliberal processes of gentrification. The emphasis on creatives and creativity as a mechanism for regeneration has led some musical cultures to become both agents and victims of artist-led gentrification. Music venues, alongside other artistic spaces, have been credited with instilling formerly 'underused' areas of post-industrial cities with a 'happening' atmosphere, while also facing closure and displacement as entrepreneurial property developers become attracted to these areas. ${ }^{173}$

${ }^{172}$ Elena Boschi, Anahid Kassabian, and Marta Quiñones, 'Introduction: A Day in the Life of a Ubiquitous Musics Listener', in Ubiquitous Musics: The Everyday Sounds We Don’t Always Notice, ed. Marta Quiñones, Anahid Kassabian, and Elena Bochi (Aldershot: Ashgate, 2013); Suzanne Cusick, 'Musicology, Torture, Repair', Radical Musicology 3 (2008), www.radical-musicology.org.uk/2008/Cusick.htm.

\footnotetext{
${ }^{173}$ For more on this, see Marie Thompson, Beyond Unwanted Sound: Noise, Affect and Aesthetic Moralism (New York: Bloomsbury, 2017).
} 
The social mutations induced by neoliberalism provide significant challenges to musicology. The (often-criticized but nonetheless persistent) analytic paradigms of great men and their music and the disciplinary investment in canon, genre, and musical autonomy are of little use in grasping the forms and functions of neoliberal music cultures. Likewise, many of the 'go-to' strategies of the critical musicologist who seeks to carve out a space for musical resistance have become ineffective. The marketization of transgression and extremity, for example, should serve as a warning against the conflation of aesthetic and political radicalism. As Steven Shaviro notes, neoliberalism has no problem with excess, insofar as it extends the field of capital investment and opens up new possibilities and processes from which to extract surplus value. ${ }^{174}$ 'Extreme' music is more likely to function as a novelty rather than a shock to thought. This raises important questions for post-Adornian investments in musical vanguardism as an inherently virtuous project.

There are important challenges too for those of us who understandably seek to challenge the over-representation of white, Eurocentric masculinity in musical discourse and practice. Projects that aim towards diversity and inclusion, whether intended or not, risk echoing the 'lean in' logics of neoliberal capitalism, with which some configurations of gender and race have become 'marketable' and have thus been 'welcomed' into the workplace. Where the archetypal worker of previous

\footnotetext{
${ }^{174}$ Steven Shaviro, 'Accelerationist Aesthetics: Necessary Inefficiency in Times of Real Subsumption', e-flux 46 (2013), www.e-flux.com/journal/accelerationistaesthetics-necessary-inefficiency-in-times-of-real-subsumption/.
} 
manifestations of liberalism was defined apropos of masculinity, the archetypal worker of contemporary neoliberalism is defined apropos of femininity: the adaptable, entrepreneurial, and precarious worker is the feminized worker. Of course, the assimilation of (some) once-excluded individuals is not to deny the persistence of oppression in a 'post-identity' society; indeed, neoliberal strategies of inclusion and diversity often work to obscure the systemic racism, patriarchy, and social inequality upon which institutions and their values are built upon. Likewise, projects that seek to incorporate individual women composers into the canon, or aim to train women and girls in music technology, risk promoting assimilation without structural critique. The inclusion of women in the canon does not serve to threaten its patriarchal construction; diversifying the technocentric fields of computer music, sound engineering, and audio production does not necessarily threaten the (gendered, racialized, classed, dis/ableist) power relations and conventions of those spaces.

It remains to be seen whether the current moment of political instability and the apparently renewed investment in the nation-state marks a mutation or the decline of neoliberalism. Nonetheless, neoliberalism's impact upon music cultures - both 'high' and 'low', 'popular' and 'art', 'DIY' and 'institutional' - should not be understated. If twenty-first-century music is to be better understood, then critical attention needs to be paid to the cultural changes that have occurred through, with, and alongside the emergence of neoliberalism since the 1970s. However, it might be that grappling with 'post-identity', 'post-genre' musical cultures requires a 'postmusicological' approach - one that refuses disciplinary isolationism and instead engages with the insights already gained by sociology, politics, geography, cultural and media studies, and beyond.

\section{$<$ A $>$ Bibliography}


$<$ Refs $>$

Adlington, Robert and Julian Johnson. 'Editorial'. Twentieth-Century Music 11/1 (2014), 3-5.

Adorno, Theodor W. Aesthetic Theory, trans. Robert Hullot-Kentor. London: Continuum, 2004.

Anderson, Benedict. Imagined Communities: Reflections on the Origins of the Spread of Nationalism. London: Verso, 1983.

Anderson, Tim J. Popular Music in a Digital Music Economy: Problems and Practices for an Emerging Service Industry. New York: Routledge, 2014.

Anon. 'Introducing the History of the Present'. History of the Present 1/1 (2011), 1-4. doi:10.5406/historypresent.1.1.0001 (accessed 28 January 2017).

—. 'Heavy Metal Genres'. Wikipedia, 2017. https://en.wikipedia.org/wiki/Heavy_metal_genres (accessed 18 January 2017).

Ashcroft, Richard and Mark Bevir. 'Pluralism, National Identity and Citizenship: Britain after Brexit'. The Political Quarterly 87/3 (2016), 355-9.

Auner, Joseph. Music in the Twentieth and Twenty-First Centuries. New York: Norton, 2013.

Badiou, Alain. The Century, trans. Alberto Toscano. Cambridge and Malden, MA: Polity, 2007.

—. The Rebirth of History, trans. Gregory Elliott. London: Verso Books, 2012. 
Bakhle, Janaki. Two Men and Music: Nationalism and the Making of an Indian Classical Tradition. Oxford: Oxford University Press, 2005.

Bauman, Zygmunt. Liquid Modernity: Living in an Age of Uncertainty. Cambridge and Malden, MA: Polity, 2007.

Bernabé, Jean, Patrick Chamoiseau, and Raphael Confiant. Éloge De La Créolité, trans. M. B. Taleb-Khyar (édition bilingue français/anglais). Paris: Gallimard, 1993.

Bernstein, David W. and Christopher Hatch, ed. Writings through John Cage's Music, Poetry, and Art. Chicago: University of Chicago Press, 2001.

Bhahba, Homi K. The Location of Culture. London and New York: Routledge, 2004.

Bohlman, Philip V. 'World Music at the "End of History"'. Ethnomusicology 46/1 (2002), 1-32.

Bond, Edward. 'Education, Imagination and the Child', in Letters 4, vol. 4, selected and ed. Ian Stuart. London: Harwood Academic, 1998.

—. The Hidden Plot: Notes on Theatre and the Stage. London: Methuen, 2000.

Born, Georgina. 'On Musical Mediation: Ontology, Technology and Creativity'. Twentieth-Century Music 2/1 (2005), 7-36.

—. 'For a Relational Musicology: Music and Interdisciplinarity, Beyond the Practice Turn: The 2007 Dent Medal Address'. Journal of the Royal Musical Association 135/2 (2010), 205-43.

Born, Georgina and David Hesmondhalgh, eds. Western Music and Its Others: Difference, Representation, and Appropriation in Music. Berkeley: University of California Press, 2000. 
Boschi, Elena, Anahid Kassabian, and Marta Quiñones. 'Introduction: A Day in the Life of a Ubiquitous Musics Listener', in Ubiquitous Musics: The Everyday Sounds We Don't Always Notice, ed. Marta Quiñones, Anahid Kassabian, and Elena Bochi. Aldershot: Ashgate, 2013. 1-14.

Bourdaghs, Michael K., Paola Iovene, and Kaley Mason, eds. Sound Alignments: Popular Music in Asia's Cold Wars. Durham, NC: Duke University Press, forthcoming.

Brackett, David. Categorizing Sound: Genre and Twentieth-century Popular Music. Berkeley: University of California Press, 2013.

Brown, Katherine Butler. 'The Social Liminality of Musicians: Case Studies from Mughal India and Beyond'. Twentieth-Century Music 3/1 (2006), 13-49.

Bürger, Peter. Theory of the Avant-Garde, trans. Michael Shaw. Minneapolis: University of Minnesota Press, 1984.

Carey, John. The Intellectuals and the Masses: Pride and Prejudice among the Literary Intelligentsia 1800-1939. London: Faber \& Faber, 1992.

Cavell, Stanley. 'Music Discomposed', in Must We Mean What We Say? A Book of Essays. Cambridge: Cambridge University Press, 1969. 181-212.

Clarke, David. 'Editorial: Twentieth-Century Music - Plural'. Twentieth-Century Music 1/2 (2004), 155-9.

—. 'Elvis and Darmstadt, or: Twentieth-Century Music and the Politics of Cultural Pluralism'. Twentieth-Century Music 4/1 (2007), 3-45.

—_. 'Elvis and Darmstadt: The IMS Cut'. Hamburger Jahrbuch für Musikwissenschaft (special issue: Zwischen 'U' und 'E') 27 (2011), 9-21. 
—. 'Different Resistances: A Comparative View of Indian and Western Classical Music in the Modern Era'. Contemporary Music Review 32/2-3 (2013), 175200.

Clyne, Anna. Steelworks. New York: Boosey \& Hawkes, 2006.

Cold War Study Group of the American Musicological Society. 'Recent Publications'. AMS, 25 February 2016. http://ams-net.org/cwmsg/recentpublications/ (accessed 4 May 2017).

Cook, Nicholas. 'Anatomy of the Encounter: Intercultural Analysis as Relational Musciology', in Critical Musicological Reflections: Essays in Honour of Derek B. Scott, ed. Stan Hawkins. Farnham: Ashgate, 2012. 193-208.

Cook, Nicholas and Anthony Pople, eds. The Cambridge History of TwentiethCentury Music. Cambridge: Cambridge University Press, 2004.

Cox, Christoph and Daniel Warner, eds. Audio Culture: Readings in Modern Music. New York and London: Continuum, 2007.

Curran, Alvin. 'The New Common Practice: Reflections of an American Composer in the Late Twentieth Century (Excerpt)'. 15 March 1994. www.alvincurran.com/writings/common.html (accessed 5 May 2017).

Cusick, Suzanne. 'Musicology, Torture, Repair'. Radical Musicology 3 (2008). www.radical-musicology.org.uk/2008/Cusick.htm (accessed 28 February 2017).

Cutler, Chris. File Under Popular: Theoretical and Critical Writings on Music. London: November Books, 1985. 
—. 'Probes 21'. RWM, 4 September 2017. podcast.

http://rwm.macba.cat/en/probes_tag (accessed 20 January 2017).

Dahlhaus, Carl. Grundlagen der Musikgeschichte. Cologne: Musikverlag Gerig, 1977.

—. Nineteenth-Century Music, trans. J. Bradford Robinson. Berkeley, Los Angeles, CA, and London: University of California Press, 1989.

Danto, Arthur C. After the End of Art: Contemporary Art and the Pale of History. Princeton: Princeton University Press, 1997.

David, Matthew. 'The Legacy of Napster', in Networked Music Cultures:

Contemporary Approaches, Emerging Issues, ed. Raphael Nowak and Andrew Whelan. London: Palgrave Macmillan, 2016. 49-65.

DeNora, Tia. Music in Everyday Life. Cambridge: Cambridge University Press, 2000.

Devroop, Chatradari. ““ ... Chasing the Canon ... ”: Opinion Piece'. SAMUS: South African Music Studies 33/1 (2013), 5-10.

Drott, Eric. 'Music as a Technology of Surveillance'. Paper presented at the American Musicological Society Annual Conference, Vancouver, 3-6 November 2016.

Dufrenne, Mikel. The Phenomenology of Aesthetic Experience, trans. Edward S. Casey. Evanston, IL: Northwestern University Press, 1989.

Eagleton, Terry. The Illusions of Postmodernism. Oxford: Blackwell, 1996.

Feller, Ross. 'Resistant Strains of Postmodernism: The Music of Helmut Lachenmann and Brian Ferneyhough', in Postmodern Music /Postmodern Thought, Studies in Contemporary Music and Culture Vol. 4, ed. Judy Lochhead and Joseph Auner. New York and London: Routledge, 2002. 249-62. 
Fink, Robert. 'Elvis Everywhere: Musicology and Popular Music Studies at the Twilight of the Canon', in Rock over the Edge: Transformations in Popular Music Culture, ed. Roger Beebe, Denise Fulbrooke, and Ben Saunders. Durham, NC, and London: Duke University Press, 2002. 60-109.

Ford, Phil. Dig: Sound \& Music in Hip Culture. Oxford: Oxford University Press, 2013.

Foster, Hal. 'Postmodernism: A Preface', in The Anti-Aesthetic:Essays on Postmodern Culture, ed. Hal Foster. Port Townsend, WA: Bay Press, 1983.

—. Recodings: Art, Spectacle, Cultural Politics. Seattle: Bay Press, 1985.

Foucault, Michel. 'The Discourse on Language', in The Archaeology of Knowledge, trans. Rupert Swyer. New York: Pantheon Books, 1971. 215-38.

Fure, Ashley. Something to Hunt, 2014. www.ashleyfure.com/something-to-hunt/ (accessed 20 January 2017).

—. Programme note for Something to Hunt, 2014. www.ashleyfure.com/something-to-hunt/ (accessed 20 January 2017).

Garrett, Charles Horishi and Carol J. Oja, 'Studying U.S. Music in the Twenty-First Century'. Journal of the American Musicological Society 64/3 (2011), 689719.

Gendron, Bernard. Between Montmartre and the Mudd Club. Chicago: University of Chicago Press, 2003. 
Gillespie, Tarleton. 'The Relevance of Algorithms', in Media Technologies: Essays on Communication, Materiality, and Society, ed. Tarleton Gillespie, Pablo J. Boczkowski, and Kirsten A. Foot. Cambridge, MA: MIT Press, 2014. 167-94.

Gopinath, Sumanth and Jason Stanyek. 'Anytime, Anywhere? An Introduction to the Devices, Markets, and Theories of Mobile Music', in The Oxford Handbook of Mobile Music Studies, vol. 1, ed. Sumanth Gopinath and Jason Stanyek. New York: Oxford University Press, 2014. 1-34.

Griffiths, Dai. 'Elevating Form and Elevating Modulation'. Popular Music 34/1 (2015), 22-44.

Griffiths, Paul. Modern Music and After. New York: Oxford University Press, 2010. Hepburn, James, ed. Arnold Bennett: The Critical Heritage. London: Routledge and Kegan Paul, 1971.

Hesmondhalgh, David. 'Review of Richard Middleton Voicing the Popular'. Journal of Popular Music Studies 21/3 (2009), 316-20.

Hobsbawm, Eric J. The Age of Extremes: The Short Twentieth Century, 1914-1991. London: Michael Joseph, 1994.

hooks, bell. Black Looks: Race and Representation. New York: Routledge, 2014.

Hume, Mike. 'A Brief History of the Phrase Manny Being Manny'. espn.com, 26 March 2009. www.espn.com/espnmag/story?id=3644816 (accessed 20 January 2017).

Huskisson, Yvonne. 'Southern Africa's Contemporary Black Composers'. Lantern 43 (1994), 23-106. 
Huyssen, Andreas. After the Great Divide: Modernism, Mass Culture, Postmodernism. Bloomington and Indianapolis, IN: Indiana University Press, 1987.

IFPI. 'Global Music Report 2017: Annual State of the Industry'. IFPI Report, 25 April 2017. www.ifpi.org/downloads/GMR2017.pdf (accessed 20 September 2017).

James, Robin. Resilience and Melancholy: Pop Music, Feminism, Neoliberalism. Winchester: Zero Books, 2015.

—. 'Is the Post- in Post-identity the Post- in Post-genre?' Popular Music 36/1 (2017), 21-32.

Jameson, Fredric. 'Periodizing the 60s'. Social Text 9/10 (1984), 178-209.

—. Postmodernism: Or, the Cultural Logic of Late Capitalism. Durham, NC: Duke University Press, 1991.

—. 'Postmodernism and Consumer Society', in The Cultural Turn: Selected Writings on the Postmodern 1983-1988. London and New York: Verso, 1998. $1-20$.

Jenkins, Keith. Why History? Ethics and Postmodernity. London: Routledge, 2001. Johnson, Walter. 'On Agency’. Journal of Social History 37/1 (2003), 113-24.

Jones, Andrew. Circuit Listening: Chinese Popular Music in the Transistor Era. Minneapolis: University of Minnesota Press, forthcoming.

Kaneda, Miki. 'Acoustics of the Everyday: Between Growth and Conflict in 1960s Japan'. Twentieth-Century Music 12/1 (2015), 71-96. 
Kassabian, Anahid. 'Would You Like Some World Music with Your Latte?

Starbucks, Putumayo, and Distributed Tourism'. Twentieth-Century Music 1/2 (2004), 209-23.

—. Ubiquitous Listening: Affect, Attention, and Distributed Subjectivity. Berkeley: University of California Press, 2013.

Kerman, Joseph. 'A Profile for American Musicology'. Journal of the American Musicological Society xviii (1965), 61-9.

Kutschke, Beate and Barley Norton, eds. Music and Protest in 1968. Cambridge: Cambridge University Press, 2013.

Kruger, Jaco. H. 'Contemporary Changing Socio-economic Patterns in Venda Cultural Practices'. Paper presented during the Travelling Institute Research Seminar, Thohoyandou, University of Venda, 2002.

Lee, Alfred. 'Spotify’s Loss Widens Despite Big Jump in Revenue'. The Information, 18 May 2017. www.theinformation.com/spotifys-loss-widens-despite-bigjump-in-revenue (accessed 22 May 2017).

León, Javier. 'Introduction: Music, Music-making and Neoliberalism'. Culture, Theory and Critique 55/2 (2014), 129-37.

Lewis, George E. 'Foreword', in Gay Guerrilla: Julius Eastman and His Music, ed. Renée Levine Packer and Mary Jane Leach. Rochester: University of Rochester Press, 2016, vii-xix

Loomba, Ania. 'Periodization, Race, and Global Contact'. Journal of Medieval and Early Modern Studies 37/3 (2007), 595-620. 
Lyotard, Jean-François. The Postmodern Condition: A Report on Knowledge, trans.

Geoffrey Bennington and Brian Massumi. Minneapolis: University of Minnesota Press, 1984.

Maciszewski, Amelia. 'Texts, Tunes, and Talking Heads: Discourses about Socially Marginal North Indian Musicians'. Twentieth-Century Music 3/1 (2006), 12144.

Makube, Tiisetso. Our Kind of Jazz Post-1994. Jazz Life: South Africa's Definitive Jazz Guide 1/1 (2013), 23-30.

Malinga, Joe M. 'Towards Realisation of South African Jazz Assuming Its Rightful Place in the Cultural Identity and Heritage of the Country'. MA diss., University of Venda, 2014.

Manabe, Noriko. 'A Tale of Two Countries: Online Radio in the United States and Japan', in The Oxford Handbook of Mobile Music Studies, vol. 1., ed. Sumanth Gopinath and Jason Stanyek. New York: Oxford University Press, 2014. 456-95.

Mannes, The New School. 'Minors'. n.d. www.newschool.edu/mannes/minors/ (accessed 29 January 2017).

—. 'Post-genre Music'. n.d. www.newschool.edu/mannes/minors-post-genre-music/ (accessed 29 January 2017).

Mapaya, Madimabe. G. 'The Anatomy of the South African Jazz Appreciation Societies'. Journal for Social Sciences 39/1 (2014), 59-65.

Margaret Thatcher Foundation. 'Thatcher, Hayek \& Friedman'. n.d. www.margaretthatcher.org/archive/Hayek.asp (accessed 14 June 2017). 
Mark, Christopher and Allan Moore. 'Editorial'. Twentieth-Century Music 1/1 (2004), $3-4$.

Mathe, Sam. 'The Voice of South African Jazz'. Jazz Life: South Africa's Definitive Jazz Guide 1/1 (2013), 23-30.

McClintock, Anne. 'The Angel of Progress: Pitfalls of the Term "Post-Colonialism"”. Social Text 31/32 (1992), 84-98.

McDonald, Glenn. 'Genre Politics'. Furialog, 21 April 2017. www.furia.com/ (accessed 22 May 2017).

Metzer, David. Quotation and Cultural Meaning in Twentieth-Century Music. Cambridge: Cambridge University Press, 2003.

—. Musical Modernism at the Turn of the Twenty-First Century. Cambridge: Cambridge University Press, 2009.

—. 'Sharing a Stage: The Growing Proximity between Modernism and Popular Music', in Transformations of Musical Modernism, ed. Erling E. Guldbrandsen and Julian Johnson. Cambridge: Cambridge University Press, 2015. 97-116.

Meyer, Leonard B. Music, the Arts, and Ideas: Patterns and Predictions in TwentiethCentury Culture. Chicago: University of Chicago Press, 1967.

- Music, the Arts, and Ideas: Patterns and Predictions in Twentieth-Century Culture, 2nd edn. Chicago: University of Chicago Press, 1994.

Middleton, Richard. 'Popular Music in the West', in The New Grove Dictionary of Music and Musicians, 2nd edn, ed. Stanley Sadie and John Tyrrell. London: 
Macmillan, 2001. Version at Grove Music Online, ed. Laura Macy (accessed 6 April 2017).

. Voicing the Popular: On the Subjects of Popular Music. New York: Routledge, 2006.

Morgan, Robert P. 'Rethinking Musical Culture: Canonic Reformulations in a PostTonal Age', in Disciplining Music: Musicology and its Canons, ed. Katherine Bergeron and Philip V. Bohlman. Chicago and London: University of Chicago Press, 1992. 44-63.

Morris, Mitchell. The Persistence of Sentiment: Display and Feeling in Popular Music of the 1970s. Berkeley: University of California Press, 2013.

Mugovhani, George, N. 'The Manifestations of the 'African Style' in the Works of Mzilikazi Khumalo’. M.Mus. diss., University of the Witwatersrand, 1998.

—. 'Venda Choral Music: Compositional Styles'. Doctoral thesis, University of South Africa, 2008.

—. 'Emerging Trends from Indigenous Music and Dance Practices: A Glimpse into Contemporary Malende and Tshigombela'. In the Southern African Journal for Folklore Studies 25/1 (2015), 81-96.

Mugovhani, George N. and Lebohang L. Nawa. 'The Socio-economic Challenges of South African Indigenous Musicians: A Case Study of Venda-based VhoNtshengedzeni Mamphodo'. The Southern African Journal for Folklore Studies (in press). 
Mugovhani, George N. and Oluranti, Ayo. 'Symbiosis or Integration: A Study of the Tonal Elements in the Choral Works of Mzilikazi Khumalo and Phelelani Mnomiya'. Muziki Journal of Music Research in Africa 12/2 (2016), 1-21.

Mugovhani, George, N. and Tshishonge, Daniel T. 'Shifting Identities in South African Indigenous Cultural Practices: A Case Study of Tshikona and Tshigombela of Vhavenda Communities in Limpopo'. South African Journal of Folklore Studies 22/2 (2012). 114-23.

Novak, David. 'The Sublime Frequencies of New Old Media'. Public Culture 23/3 (2011), 603-34.

O’Connell, John Morgan. ‘A Staged Fright: Musical Hybridity and Religious Intolerance in Turkey'. Twentieth-Century Music 7/1 (2010), 3-29.

Pandora Media. 'Pandora 10-K, December 2016'. 10-K Annual Report to the U.S. Securities and Exchange Commission, 15 February 2017. http://investor.pandora.com/Doc/Index?did=39496989.

Pasler, Jann. 'Sonic Anthropology in 1900: The Challenge of Transcribing NonWestern Music and Language'. Twentieth-Century Music 11/1 (2014), 7-36.

Piekut, Benjamin. 'No Common Practice: The New Common Practice and its Historical Antecedents'. New Music Box, 1 February 2004. www.newmusicbox.org/articles/No-Common-Practice-The-New-CommonPractice-and-its-Historical-Antecedents/ (accessed 5 May 2017).

Prendergast, Mark. The Ambient Century: From Mahler to Trance: The Evolution of Sound in the Electronic Age. London: Bloomsbury, 2000. 
Prey, Robert. 'Musica Analytica: The Datafication of Listening', in Networked Music Cultures: Contemporary Approaches, Emerging Issues, ed. Raphael Nowak and Andrew Whelan. London: Palgrave Macmillan, 2016. 31-48.

Qureshi, Regula Burckhardt. 'Mode of Production and Musical Production: Is Hindustani Music Feudal?', in Music and Marx: Ideas, Practice, Politics, ed. Qureshi. New York: Routledge, 2002.81-105.

Ranciére, Jacques. The Politics of Aesthetics: The Distribution of the Sensible, trans. Gabriel Rockhill. London and New York: Continuum International, 2004.

- Dissensus: On Politics and Aesthetics, ed. and trans. Steven Corcoran. London and New York: Continuum International, 2010. 134-51.

Rollefson, J. Griffith. 'Review of Martin Munro, Different Drummers: Rhythm and Race in the Americas'. Twentieth-Century Music 10/1 (2013), 156-63.

Ross, Alex. The Rest Is Noise: Listening to the Twentieth Century. London: Harper Perennial, 2009.

—_. 'Julius Eastman’s Guerrilla Minimalism'. New Yorker, 23 January 2017.

Saussure, Ferdinand de. Cours de linguistique générale, ed. Charles Bally and Albert Sechehaye with Albert Riedlinger. Paris, Payot, 1960.

Shaviro, Steven. 'Accelerationist Aesthetics: Necessary Inefficiency in Times of Real Subsumption'. e-flux 46 (2013). www.e-flux.com/journal/accelerationistaesthetics-necessary-inefficiency-in-times-of-real-subsumption/ (accessed 28 February 2017).

Shaw, Caroline. 'Passacaglia', Partita. (Score not available.) 
Smith, Leo. Notes (8 pieces) Source a New World Music: Creative Music. Chicago: Corbett vs. Dempsey [1973] 2015, n.p.

Spivak, Gayatri Chakravorty. 'Dialogue: World Systems \& the Creole'. Narrative 14/6 (2006), 102-12.

Streeck, Wolfgang. 'The Return of the Repressed', trans. Rodney Livingstone. New Left Review 104 (2017), 5-18.

Swift, Richard. '1/XII/99: Tonal Relations in Schoenberg's Verklärte Nacht'. 19thcentury Music 1/1 (1977), 3-14.

Tanke, Joseph J. 'What is the Aesthetic Regime?' Parrhesia: A Journal of Critical Philosophy 12 (2011), 71-81. http://parrhesiajournal.org/parrhesia12/parrhesia12 tanke.pdf (accessed 11 June 2017).

Taruskin, Richard. The Oxford History of Western Music. New York: Oxford University Press, 2005.

Taylor, Timothy. Beyond Exoticism: Western Music and the World. Durham, NC: Duke University Press, 2007.

- Music and Capitalism: A History of the Present. Chicago: University of Chicago Press, 2015.

Thompson, Marie. Beyond Unwanted Sound: Noise, Affect and Aesthetic Moralism. New York: Bloomsbury, 2017.

Toop, David. Ocean of Sound: Aether Talk, Ambient Sound and Imaginary Worlds. London: Serpent's Tail, 1995.

Tovey, Donald Francis. The Main Stream of Music and Other Essays. Cleveland and New York: Meridian Books, 1949. 
Treitler Leo. Music and the Historical Imagination. Cambridge, MA: Harvard University Press, 1989.

Weiss, Peter. Die Ästhetik des Widerstands, 3 vols. Frankfurt: Suhrkamp Verlag, $1975,1978,1981$.

Whitman, Brian. 'How Music Recommendation Works - and Doesn't Work'. Variogram. 11 December 2012. https://notes.variogr.am/2012/12/11/howmusic-recommendation-works-and-doesnt-work/ (accessed 22 May 2017).

Wong, Deborah. 'Sound, Silence, Music: Power'. Ethnomusicology 58/2 (2014), 34753.

Yang, Hon-Lun. '1968 - Womanhood and Gender Roles in Model Plays of the PRC and Movie Musicals of Hong Kong', in Music and Protest in 1968, ed. Barley Norton and Beate Kutschke. Cambridge: Cambridge University Press, 2013. $222-36$.

_ _ 'Cosmopolitanism and Sound Alignments: Cantonese Cover Songs from Hong Kong Films of the 1960s', in Sound Alignments: Popular Music in Asia's Cold Wars, ed. Michael K. Bourdaghs, Paola Iovene, and Kaley R. Mason. Durham, NC: Duke University Press, forthcoming.

—_. 'Curb that Enticing Tone: Music Censorship in the PRC', in The Oxford Handbook of Music Censorship, ed. Patricia Hall. Oxford: Oxford University Press, 2016. www.oxfordhandbooks.com/view/10.1093/oxfordhb/9780199733163.001.000 1/oxfordhb-9780199733163-e-22 (accessed 20 September 2017). 
—. 'Diaspora, Music, and Politics: Russian Musical Life in Shanghai during the Inter-War Period', in Music and Politics, ed. Pauline Fairclough. Farnham: Ashgate, 2013. 261-78.

—. 'Liszt in Socialist China', in Liszt and His Legacy, ed. James Deaville and Michael Saffle. New York: Pendragon Press, 2014. 348-66.

—. 'The Shanghai Conservatory, Chinese Musical Life, and the Russian Diaspora: 1927-1949'. Twentieth-Century China 37/1 (2012), 73-95.

—_. 'Unravelling The East is Red: Socialist Music and Politics in the People's Republic of China', in Composing for the State: Music in Twentieth-Century Dictatorships, ed. Esteban Buch, Igor Contreras Zubillaga, and Manuel Deniz Silva. New York: Ashgate/Routledge, 2016. 51-68.

Yang, Hon-Lun and Michael Saffle, eds. China and the West: Music, Representation, and Reception. Ann Arbor: University of Michigan Press, 2017.

Yang, Hon-Lun, Simo Mikkonen, and John Winzenburg. Networking the Russian Diaspora Russian Musicians and Musical Activities in Interwar Shanghai. Honolulu, Hawaii: University of Hawaii Press, forthcoming. 